\title{
Gilberto Freyre e Amaury de Medeiros: tensões entre culto à tradição e messianismo sanitário (Recife, 1923-1926)
}

Gilberto Freyre and Amaury de Medeiros: tensions between cult of tradition and sanitary messianism (Recife, 1923-1926)

hitps://doi.org/10.1590/1982-02672020v28e13

\section{TELMA DE BARROS CORREIA'}

https://orcid.org/0000-0001-8002-8748

Universidade de São Paulo / São Paulo, SP, Brasil

RESUMO: $\bigcirc$ artigo aborda afinidades e antagonismos entre o jornalista e sociólogo Gilberto Freyre (1900-1987) e o médico e sanitarista Amaury de Medeiros (1893-1928). Trata do protagonismo de ambos na criação do Centro Regionalista do Nordeste (abril de 1924), na Semana das Árvores (novembro de 1924) e no Primeiro Congresso Regionalista do Nordeste (fevereiro de 1926). $\bigcirc$ artigo aborda as convergências entre estes dois homens na defesa da identidade regional e do estilo neocolonial de arquitetura e suas divergências de avaliação dos mocambos e dos valores da cidade e da arquitetura residencial herdadas do passado. Discute o embate travado entre Freyre e Amaury, este no comando de uma ampla intervenção sanitária em Pernambuco e aquele empenhado em combater a ênfase conferida à higiene naquele momento.

PALAVRAS-CHAVE: Regionalismo. Higiene. Arquitetura. Cidade. Tradição.

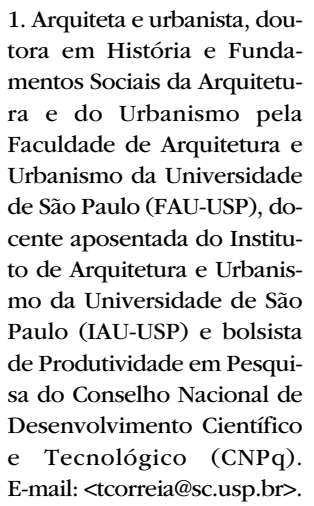

E-mail: <tcorreia@sc.usp.br>. 
ABSTRACT: The aim of this article is to analyze the affinities and antagonisms between the journalist and sociologist Gilberto Freyre (1900-1987) and the physician and sanitarist Amaury de Medeiros (1893-1928). It studies their protagonism in the creation of the Centro Regionalista do Nordeste (april 1924), in the Semana das Árvores (november 1924) and in the Primeiro Congresso Regionalista do Nordeste (february 1926). The article discusses the convergence between these two men in the defense of regional identity and colonial revival style and their divergences about the mocambos and the qualities of the city and residential architecture inherited from the past. It discusses the debate between Amaury, in charge of a wide sanitary intervention in Pernambuco, and Freyre, committed to fight the emphasis on hygiene at that moment.

KEYWORDS: Regionalism. Hygiene. Architecture. City. Tradition. 
Amaury de Medeiros e Gilberto Freyre deixaram o Recife na adolescência e à cidade retornaram - festejados como talentos dos mais promissores - em datas 3. Fernandes (1923, p. 3). 4. Gilberto Freyre (1923, p. 1). próximas: aquele no final de janeiro de 1923 e este em março do mesmo ano. De Freyre partiram informações desencontradas acerca do momento em que conheceu Amaury: em um artigo, de julho de 1923, sugeriu já ter travado conversa com o médico; em outro, de dezembro de 1928, declarou terem sido apresentados na tarde de 28 de abril de 1924, na reunião que deu origem ao Centro Regionalista do Nordeste. ${ }^{2} O$ certo é que nos cerca de dois anos e meio seguintes, até o médico deixar o Recife em outubro de 1926, Amaury e Freyre estabeleceram um convívio intelectual intenso e instigante. Eram jovens atrevidos, com grande domínio da escrita, algumas fortes afinidades e diferenças difíceis de conciliar. Guardavam afinidades estéticas e divergências frente ao tema da higiene. O sociólogo nunca escondeu sua aversão ao "messianismo hygienico" que atribuía ao médico sanitarista e clínico. Amaury, por sua vez, não se negou a chamar de "pieguice" a defesa de mocambos, que tinha em Freyre seu mais notório intérprete no Recife. Nesses termos, conseguiram firmar uma relação de cooperação e, até, de admiração e de amizade.

Em meados da década de 1920, o recifense Gilberto Freyre (19001987) era um jovem muito prestigiado nos meios intelectuais locais, recémchegado de cinco anos de estudos nos Estados Unidos. Colaborava com revistas e, desde 1918, com o Diario de Pernambuco. Ao retornar ao Recife, em março de 1923, foi recebido pela coluna do mais influente jornalista da cidade, Annibal Fernandes, com elogios à "[...] cultura invulgar, na sua idade [...] desse espirito moço e fulgurante". ${ }^{3}$ Em homenagem recebida no Colégio Americano Batista, foi saudado por Luiz de França Pereira (1 872-1925) - seu ex-professor e então presidente da Academia Pernambucana de Letras - como "[...] uma das mais fortes organizações intellectuaes da nova geração". " Sua trajetória e obra posteriores, amplamente conhecidas, dispensam comentários.

Amaury de Medeiros (1893-1928) era um inquieto médico nascido no Recife e formado em 1916 no Rio de Janeiro, onde atuara como clínico especialista em doenças pulmonares, dirigira os serviços médicos da Cruz Vermelha Brasileira e coordenara uma ruidosa Cruzada Nacional Contra a Tuberculose. Em fevereiro de 1923, assumira a chefia do Departamento de Saúde e Assistência de Pernambuco, nomeado por seu sogro, o governador Sergio Loreto. Nesse cargo, coordenou uma ampla reforma dos serviços e uma intensa atividade de propaganda sanitária, inspeção de moradias, escolas e fábricas, fundação de postos de saúde, criação e reforma de hospitais e intervenções urbanas, por meio de obras de 
5. Cf. Correia (2004, 2011, 2013, 2014a, 2014b) drenagem de áreas alagadas. Essa ação resultou, entre muitas outras coisas, na criação da fundação A Casa Operária, na criação da Praça Oswaldo Cruz e na urbanização do Derby e de Boa Viagem.

Este artigo se detém na relação intelectual então estabelecida entre esses dois interlocutores, explorando suas convergências, suas fortes divergências e o sentido de seus embates no âmbito do Centro Regionalista do Nordeste. No tratamento dessas questões, o artigo se baseia em escritos e falas de Gilberto Freyre e Amaury de Medeiros e em fontes diversas - livros, jornais, revistas e projetos de arquitetura. As questões referentes ao estilo neocolonial, à reforma da moradia e da cidade e à defesa do patrimônio construído foram tratadas com apoio nos trabalhos da autora e em sua experiência de ensino e pesquisa. ${ }^{5} \bigcirc$ embate - que se acirrou, no Brasil, nas últimas décadas do século XIX e primeiras do XX - entre a higiene e a cidade herdada do passado é um assunto muito estudado por arquitetos e historiadores. A proposta deste artigo é oferecer uma contribuição ao tema, centrada nas especificidades do caso do Recife na década de 1920 e na ação de dois indivíduos julgados relevantes. Para tal - sempre considerando as conexões do lugar e dos personagens com o país e a cultura da época -, prescinde-se de discutir análises sobre o tema formuladas com base em casos de outras cidades, referentes a outros momentos históricos ou que se pretendem de alcance nacional.

Além de introdução e conclusão, o artigo tem outras cinco partes: duas tratam das afinidades entre Freyre e Medeiros em torno do regionalismo e do estilo neocolonial de arquitetura e duas tratam de suas divergências teóricas acerca do mocambo e do tratamento a ser dado à cidade do passado. Contudo, como as coisas costumam ser bem mais complicadas que aparentam, o item 6 mostra um médico que, apesar do sanitarismo exaltado do discurso, adota uma prática de grande respeito pela cidade antiga e um sociólogo que, embora aplicado ao estudo e à valorização de tradições, não deixou de se comprometer com iniciativas de destruição/desfiguração de prédios relevantes para a história do lugar. $\bigcirc$ artigo faz amplo uso de citações e imagens: são as brasas que o aquecem, trazendo o tempo, os indivíduos, a cidade...

\section{O REGIONALISMO}

movimento regionalista, que ahi no Recife foi por algum tempo o que deu sal á monotonia da vida, teve em Amaury de Medeiros um enthusiasta, que com a maior vivacidade se identificou com as campanhas emprehendidas. Precisamente no Centro Regionalista do Nordeste, que 
nesse tempo reunia-se na residencia do meu mestre e amigo illustre, o professor Odilon Nestor, conheci uma tarde, o então director da Saude Publica de Pernambuco. Eu fôra a convite do professor Odilon Nestor, e tinha sido um dos primeiros a chegar. E admirava com o dr Moraes Coutinho, esse fino e gentil temperamento de estheta, os quadros e os lindos objectos de arte que fazem a casa de Odilon Nestor um dos mais suggestivos interiores da bella capital pernambucana, quando chegou Amaury de Medeiros. Deu-me logo a impressão de uma dessas pessoas cujo enthusiasmo é irresistível. E através da reunião toda, elle foi sempre quem vibrou mais forte a nota de enthusiasmo, como querendo que num instante todas as idéas do movimento regionalista dominassem numa victoria brilhante. Fazia-the mal um meio sorriso que no meio daquella confiança, daquella fé enthusiastica, daquelle idealismo absoluto, duvidasse um pouco da importancia ou da conveniencia do esforço e do programma que alli reunia, em volta de um chá muito bem feito e de uns bôlos de gomma magnificos, temperamentos tão diversos. ${ }^{6}$

Assim, Gilberto Freyre - com o pseudônimo Jorge Rialto - relatou a reunião, a partir da qual se aproximou de Amaury de Medeiros. A iniciativa dessa reunião ocorreu em meio a um forte sentimento de apreço pelas coisas locais do presente e do passado, que se traduziu na criação do Centro Regionalista do Nordeste, no qual ambos tiveram grande protagonismo.

Na década de 1920, o persistente nativismo pernambucano assumiu a forma de um sentimento cultural regionalista que varreu o Recife e teve seu ápice no período correspondente ao governo de Sergio Loreto (1923-1926). Intelectuais e jornalistas como Manuel Caetano e Carlos Lyra entregaram-se ao estudo e à coleção de coisas do passado e da tradição local. Ascenso Ferreira construiu um amplo repertório de lendas, toadas, poemas e anedotas, vinculado a temas regionais e populares. ${ }^{7}$ Valdemar de Oliveira, Samuel Campello, Mario Sette e Humberto Carneiro dedicaram-se a obras literárias ou teatrais de viés regionalista. Nelson Ferreira executava obras musicais de compositores locais e do folclore pernambucano. Manoel Bandeira (o desenhista) e Fedora Monteiro retratavam aspectos da paisagem local. A Revista do Norte, publicada por José Maria de Albuquerque e Mello, não desprezava os temas regionais em seu compromisso com a renovação artística. Annibal Fernandes dirigia o foco de suas crônicas à cidade do Recife, que criticava, entre outras coisas, pelo avanço das influências externas na arquitetura e no urbanismo. Odilon Nestor de Barros Ribeiro escrevia poemas evocando lugares do Recife antigo, enquanto reunia objetos antigos em sua casa. Entre esses homens, a valorização de heranças do passado e a reverência às tradições e coisas locais vinham, no mais das vezes, acompanhadas de militância pela proteção de bairros e prédios antigos.

Ao retornar ao Brasil em 1923, Freyre postulou a necessidade de formar e difundir um sentimento de apreço pelo passado, pela tradição e pelos valores locais. Deplorou a perda das tradições culinárias - que estava retirando das 
8. Freyre (1924d. p. 2).

9. Id. (1926d, p. 3).

10. Medeiros (1928, p. 20). mesas bacalhoadas de coco, feijoadas, pirões, mocotós e buchadas -, alertando que "[...] o paladar é talvez o ultimo reducto do espirito nacional; quando ele se desnacionaliza está desnacionalizado tudo o mais". ${ }^{8}$ Dedicou-se a percorrer o que restara dos bairros antigos do Recife e a escrever artigos, nos quais defendia os valores da arquitetura do passado e da fisionomia tradicional da cidade. Lamentou a destruição de lugares e a reforma de prédios como a Sé de Olinda e a igreja de Casa Forte. Poucos anos depois, descreveu seu estado de espírito e sua atitude em relação à cidade naqueles dias:

Eu acabara de chegar dos Estados Unidos e da Europa que nem um Fradique. Jacobino. Tradicionalista e futurista ao mesmo tempo. Querendo isto aqui tudo como no tempo da Lingueta. Preferindo o caracter da cidade com os maus cheiros á ausencia de caracter. Elogiando as ruas estreitas. Levando Gagarin e De Garo a recantos de uma sujice oriental p'ra elles pintarem. Comprando peixe frito de tabuleiro. Exaltando o pateo de São Pedro sobre o parque do Derby. Escrevendo cousas horriveis contra a Linha Recta nos velhos burgos como o Recife. Chorando a derrubada do Corpo Santo. Chorando a derrubada dos arcos. Chorando a derrubada das gamelleiras. Achando safadissimas as mobilias novas, amarellinhas, e as casas novas, sarapintadas de anjinhos, ramalhetes, rosas abertas e em botão - e apontando para os velhos casarões brancos ou côr ocre amarello e de doces alpendres; e para os velhos jacarandás. E achando safadissima tambem a imitação da culinaria europea, em prejuizo da nossa velha cozinha de engenho. ${ }^{9}$

No ambiente e na família em que nasceu, seria difícil a Amaury deixar de cultivar o gosto pela história e pelas coisas antigas. Seu pai - o advogado, escritor e professor de francês Bianor de Medeiros - escreveu obras literárias comprometidas com a apreensão e expressão da "alma brasileira". Buscou no tupi nomes para quatro de seus cinco filhos: Caramuru, Coaracy, Abaeté e Jandyra. Cultivou um nacionalismo herdeiro do nativismo pernambucano do século XIX, praticado no Instituto Arqueológico e Geográfico, do qual foi sócio e, em várias ocasiões, membro da diretoria. Com palestras e poemas de sua autoria, foi uma presença constante em eventos que celebraram as lutas pela independência ocorridas no Estado no século XIX. Frei Caneca (1779-1 825) era o patrono da cadeira de número três da Academia Pernambucana de Letras, fundada por Bianor, que escreveu sua biografia. Na família materna de Amaury, a atitude nativista encontrou expressão nos tios José, Joaquim e João de Góes Cavalcanti, fundadores da Sociedade Literária José de Alencar, que se reunia - a partir de 1902 - na residência dos Góes Cavalcanti em Parnamirim e da qual Bianor também era sócio. Tendo crescido nessa família, onde o passado era constantemente invocado como inspiração para o presente, não é de se estranhar que Amaury tenha se definido, em 1928, como alguém "[...] com alma para secretario perpetuo de instituto histórico". 10 Ao ser convocado por $O$ Jornal a fazer 
um relato do Quarto Congresso de Higiene, ocorrido em 1928 na Bahia, deteve-se menos no evento que nos "[...] grandes monumentos de arte antiga que cobrem e enriquecem as bellas collinas de São Salvador". ${ }^{11}$

Centro Regionalista do Nordeste aproximou esses dois homens. Coube ao professor da Faculdade de Direito do Recife Odilon Nestor de Barros Ribeiro (1875-1969) a iniciativa de convocar o primeiro encontro do grupo e a escolha dos convidados. Na sua casa à Rua do Paissandu teve lugar, em 28 de abril de 1924, o encontro que reuniu, além do dono da casa, o bacharel em direito Antonio Ignacio de Barros Ribeiro (1888-1938), o médico Alfredo de Moraes Coutinho Filho, Amaury, Gilberto Freyre e seu pai, o juiz Alfredo Freyre (1875-1961) (figura 1). Odilon Nestor foi indicado presidente do Centro, e Gilberto Freyre, secretário-geral. Desses seis indivíduos, os três vinculados ao Departamento de Saúde e Assistência (DSA) do governo estadual - Amaury como diretor, Antonio Ignacio como chefe da Secretaria Geral e Moraes Coutinho como chefe da Inspetoria de Estatística, Propaganda e Educação Sanitária - foram presenças constantes nas reuniões da associação e tiveram papel central em suas atividades. Ao grupo inicial juntaram-se outros membros, entre os quais havia professores, escritores, médicos, jornalistas, políticos e advogados; homens com grande influência na imprensa e no governo, parlamentares, empresários, donos de engenhos e de usinas.
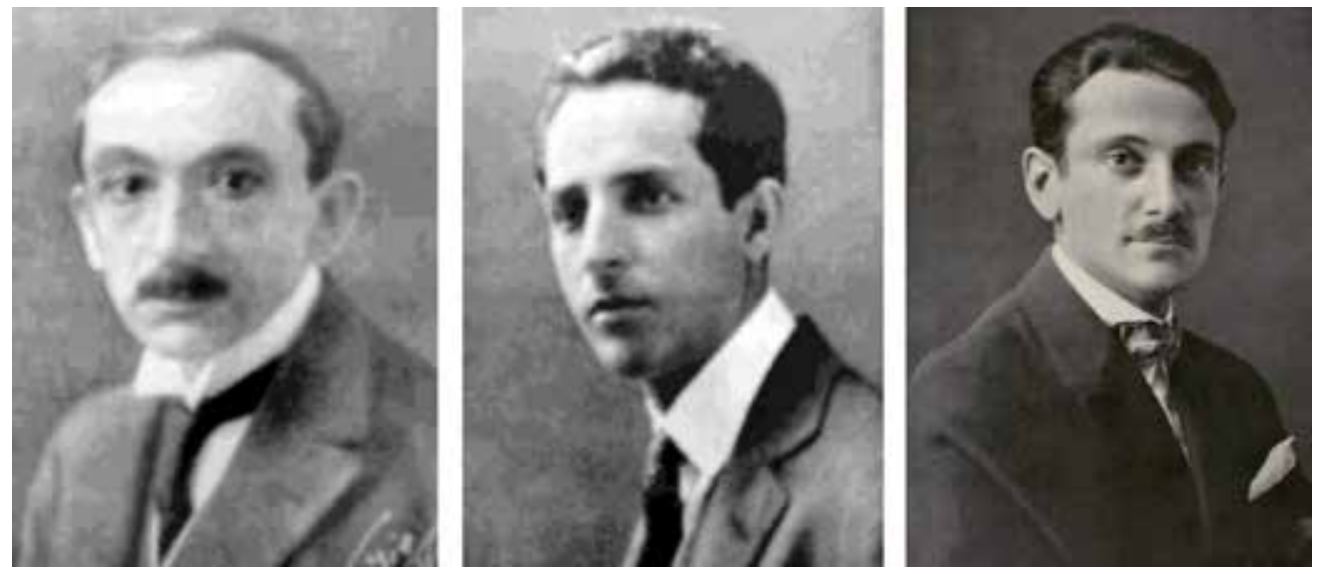

Figura 1 - Três dos fundadores do Centro Regionalista do Nordeste: Odilon Nestor de Barros Ribeiro, Alfredo de Moraes Coutinho Filho e Amaury de Medeiros. Illustração Brasileira, Rio de Janeiro, a. V, n. 46, junho 1924.

Os encontros do grupo ocorriam sempre na casa de Odilon Nestor, entre as 17 e 18 horas de terças-feiras, em volta de uma mesa servida com chá, sequilhos, doces e sorvetes da região. ${ }^{12} \mathrm{Na}$ segunda reunião, uma semana
11. Quarto Congresso Brasileiro... (1928, p. 7).

12. Freyre (1996, p. 49). 
13. Centro Regionalista do... (1924b, p. 1).

14. Ibid. (1924b, p. 1).

15. Medeiros (1924). após a primeira, Moraes Coutinho leu o programa de ação do Centro, que definia os objetivos da associação: "[...] desenvolver o sentimento da unidade do Nordeste, já tão claramente caracterisada na sua condição geographica e evolução historica, e ao mesmo tempo, trabalhar em prol dos interesses da região nos seus aspectos diversos: sociaes, economicos e culturaes." Indicava ser a associação "livre das injuncções das correntes partidarias" e ter o propósito de defender os interesses do Nordeste perante o governo da União. Descrevia seus membros como "bons elementos da inteligencia nordestina". ${ }^{13}$

Nesse segundo encontro, Amaury leu o manuscrito do artigo intitulado "Pernambuco e o problema sanitario do Nordeste", no qual divulgava os trabalhos que o DSA vinha realizando e traduzia para o âmbito da saúde a abordagem regional proposta pelo Centro. Uma nota sobre a reunião, publicada no Diario de Pernambuco - sem autoria, mas cujo estilo denuncia Gillberto Freyre - elogia o artigo: "[...] encara o auctor nosso problema de saude sob um criterio rasgadamente nordestino". ${ }^{14}$ Amaury iniciou o artigo apontando os limites geográficos da região considerada - aquela que se estende de Alagoas ao Ceará - e assinalando seus aspectos comuns. Os regionalistas entendiam o "Nordeste" como unidade econômica, política, geográfica e cultural, que - pouco inclinados à modéstia reconheciam como berço da nação e detentor de uma vigorosa cultura capaz de resistir às investidas homogeneizadoras do capitalismo. Seus limites correspondiam à abrangência territorial da Confederação do Equador, o que não precisou ser lembrado por Amaury, que salientou as afinidades entre os cinco estados:

O homem do nordeste, aqui ou ali, physica e moralmente é sempre o mesmo, iguaes são os seus costumes e mesmas as suas aspirações; as ligeiras differenças, que se notam no povo do littoral, quase não conseguem chegar ao interior e o matuto e o sertanejo são inteiramente iguaes em toda a região.

A terra tambem não differe, são iguaes os coqueiros que bordam o oceano, são iguaes os rios espraiados do littoral, iguaes as arvores das florestas e o matto quase rasteiro do agreste, iguaes os espinhos que cobrem as terras do sertão. $O$ mesmo sol no verão e a mesma chuva no inverno, um a queimar por toda a parte a vegetação que o outro depois ressuscita. ${ }^{15}$

Argumentou que às suas características comuns corresponderia um poderoso amálgama, exigindo considerar a higiene - que entendia, por definição, não ter fronteiras - no conjunto dos cinco estados. Assim, defendia uma ação de saúde pública de âmbito regional, que seria impulsionada a partir de Pernambuco. 
Alguns meses depois, Freyre abordou os propósitos do centro, agora pelo viés da cultura, sugerindo aspectos que interessavam conservar ou usar como motivos para inovação:

Do Nordeste do Brasil é o typo de "casa grande" de engenho que, através da emoção e da technica de architectos como o sr. Armando de Oliveira, será nossa grande contribuição á arte e á vida do Brasil.

Do Nordeste são esses "côcos" e dansas de caboclos vaqueiros e "cabras" e mulatos de engenhos, esses reis do Congo e esses maracatús e essas macabras historias meio-lendas de Cabelleiras, esses Zé Pereira com o seu não sei que de agudamente saudoso - toda uma riqueza de motivos para estylização em bailados, em musicas, em pinturas muraes. ${ }^{16}$

Em outra ocasião, respondeu aos que atribuíam ao centro um viés passadista: "O movimento regionalista no Nordeste não é necrophilo. Não tem a superstição do passado. Ama, porem, nas velhas coisas, a sugestão de brasilidade, o traço, a linha de belleza a ser continuada pelo Brasil."17 $\bigcirc$ programa regionalista era amplo e logo começou a ser posto em prática:

Organisar conferencias, exposições de arte, visitas e excursões; Manter em sua séde biblioteca e sala de leitura, onde se achem representadas as producções intellectuaes do Nordeste, no passado e no presente; promover cada anno ou de dois em dois annos, em uma cidade do Nordeste, um congresso regionalista e editar uma revista de cultura, "O Nordeste", dedicada especialmente ao estudo das questões nordestinas e ao registro da vida regional. ${ }^{18}$

A primeira iniciativa foi a promoção de um concurso de fotografia, julgado em outubro de 1924, que premiou "A Jaqueira", de Horacio Alves. Seguiu-se a "Semana das Árvores", em novembro de 1924, na qual a flora do Nordeste foi tratada pelo viés artístico, literário, científico e urbanístico. As palestras, apresentações musicais e de poesia celebraram as ávores e proclamaram o compromisso de proteção da flora local contra a destruição e a mutilação. As sessões foram prestigiadas por estudantes, professores, políticos, membros da administração estadual, médicos, jornalistas e homens de letras. Entre os conferencistas estavam Freyre e Amaury.

"O Recife e as Árvores" foi o tema abordado por Gilberto Freyre, que lembrou homens que arborizaram o Recife no passado, como Nassau com seu parque e o governador Tomás de Mello, no século XIX, com as gameleiras que se converteriam em uma marca da cidade. Atribuiu a derrubada das gameleiras, assim como a demolição ou reforma de igrejas e arcos no século XX, à "mania do 
reformismo para modernisar", aos "caprichos de symetria dos senhores prefeitos" e à "esthetica dos engenheiros". Elogiou as cores e formas da flora local e o prefeito Antonio de Góes por ser "amigo das arvores", embora sem deixar de censurá-lo pela sua preferência pelas estrangeiras e de lamentar a "orgia da figueira benjamin" que estaria promovendo. ${ }^{19}$

A fala de Amaury integrou as atividades do último dia da Semana, que teve lugar no parque - por ele concebido e dotado de espécimes da flora local - da Escola Normal do Estado (figura 2).

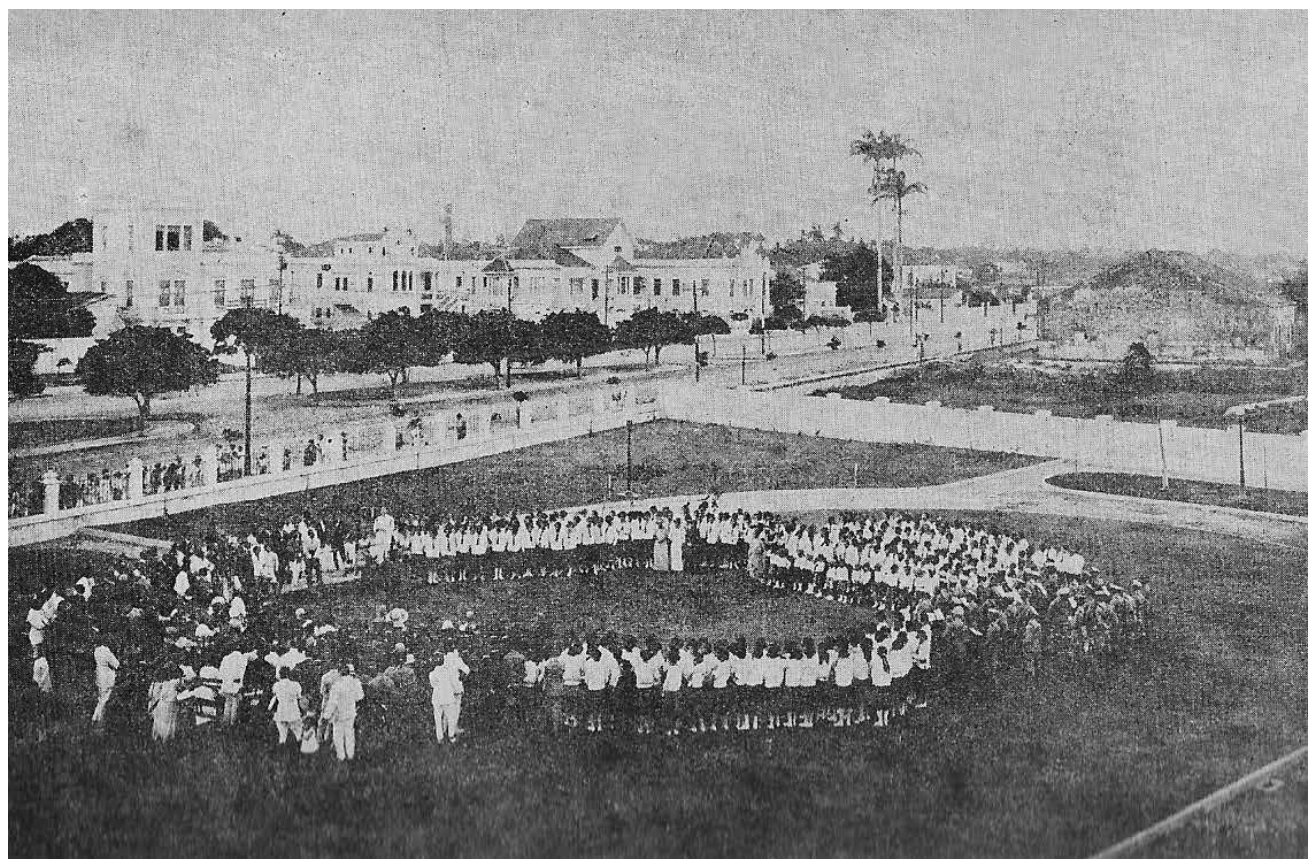

Figura 2 - Amaury fazendo a palestra "A Physionomia das Arvores" durante a Semana das Árvores, no jardim da Escola Normal. Medeiros, 1926a, p. 127.

Na palestra, Amaury citou "Burity Perdido", de Afonso Arinos, "O MataPau", de Monteiro Lobato, assim como Euclydes da Cunha, Augusto dos Anjos, Olegario Marianno e Juvenal Galeno. Ao lado de uma descrição da forma das espécies, aventurou-se em uma curiosa "psicologia" das árvores nordestinas, identificando nelas sugestões de bondade, simplicidade, resistência, força, preguiça, imprevidência e maldade. Segue um trecho:

O nosso coqueiro, pacifico e displicente, é uma arvore simples e bôa; seus fructos são fartos e polidos, suas flores têm um perfume leve, sua folhagem longa e angulante, feita para bailar perpetuamente com o vento, tem um cheiro suave de praias brancas [...]. 
Ha arvores fascinorosas, arvores terriveis, cuja folhagem, cujo tronco, cujas raizes, cujo fructo, cuja latez que corre de suas veias, dão, desde logo, a impressão do veneno e da maldade; seus fructos ninguem come, seu tronco de nada serve, sua sombra é irregular, sua copa feia e mysteriosa. Assim é o matapao que muitas vezes brota pelos beiraes das casas velhas de architectura ingenua e bôa, que a arvore terrivel parece ter préssa de destruir; assim é o gameleiro que vemos todos os dias agarrado as outras arvores em abraços fataes. ${ }^{20}$

Assim, mobilizou em torno da natureza tropical noções médicas e sanitárias e valores morais e estéticos que compartilhava. $\bigcirc$ dendezeiro, o mata-pau e o gameleiro são alinhados aos espécimes que julgava nocivos, ao relacioná-los a "crendices" ou a condições anti-higiênicas, aestéticas ou "desleais" com outras árvores, tais como atração de urubus, beirais arruinados e estrangulamento da hospedeira. Em outro trecho da fala, o poeta e o sanitarista cedem lugar ao paisagista e Amaury critica a prática de poda de árvores em ruas e praças:

Não concordo com aquelles que querem as arvores barbeadas e de cabellos aparados a la garçonne, como toda gente.

As arvores aparadas, todas iguaes em semi-espheras, ou pyramides ou cylindros verdes, absolutamente symetricas, lembram-me soldados formados em linha pelas calçadas, como em grande e inexpressiva parada [...].

A acceitar, como bôa, tal pratica, melhor fora substituir as arvores por modelos de cimento armado, pintados de verde ao longo das ruas, ou disseminados pelos parques. Isto seria muito mais pratico e muito mais barato, bastando fincar no solo, como postes, as arvores artifices e ellas estariam desde logo proporcionadas e promptas para dar sombra ao resto da vida [...].

Os parques devem dar a impressão de que os motivos decorativos ali reunidos são motivos reaes que o accaso juntou e que por ali ficaram com a sua physionomia natural. ${ }^{21}$

Outra iniciativa que pode ser associada à ação do Centro Regionalista foi a publicação do Livro do Nordeste, em 1925, em comemoração ao centenário do Diario de Pernambuco. Seu organizador, Gilberto Freyre, apresentou o livro como um "[...] esforço de estimativa em torno de alguns dos valores mais caracteristicos da região; pequeno inquerito ás tendencias da vida nordestina". ${ }^{22}$ A obra incluiu poemas, gravuras, estatísticas e artigos, vários deles escritos por membros do centro. Nela Freyre abordou o tema da vida social. Amaury não contribuiu com produção própria, mas de forma indireta, por meio de quadros com dados estatísticos do Recife produzidos pelo órgão que dirigia, o DSA.

O Primeiro Congresso Regionalista do Nordeste ocorreu no Recife, em fevereiro de 1926. Dele participaram políiticos, jornalistas, médicos, professores,
20. A Semana das... (1924,

p. 1) e Echos da "Sema-

na... (1924, p. 4).

21. A Semana das... (1924, p. 1) e Echos da "Sema-

na... (1924, p. 4).

22. Freyre (1979a, p. 3). 
23. Primeiro Congresso Regionalista... (1926a, p. 3) e $1^{\circ}$ Congresso Regionalista... (1926a, p. 1). poetas, cronistas, historiadores e um urbanista. Envolveu sessões com discussões de teses e apresentações de trabalhos, música e poesia, uma exposição e um jantar regional, além de visitas a lugares antigos (engenho Megahype, sítio dos Guararapes, Olinda e lgarassu) e a prédios concebidos por ou sob a orientação de Amaury, como a Vila Operária Paz e Trabalho e algumas construções de "inspiração colonial" (Grupo Escolar Amaury de Medeiros e pavilhões nos hospitais Oswaldo Cruz e de Doenças Mentais). Na sessão inaugural, Moraes Coutinho fez conferência na qual apresentou os objetivos do Centro, versos foram recitados por Samuel Campello e por Ascenso Ferreira e o músico alagoano Manoel de Lima, "O Ceguinho", tocou viola e realejo (figuras 3 e 4). ${ }^{23}$

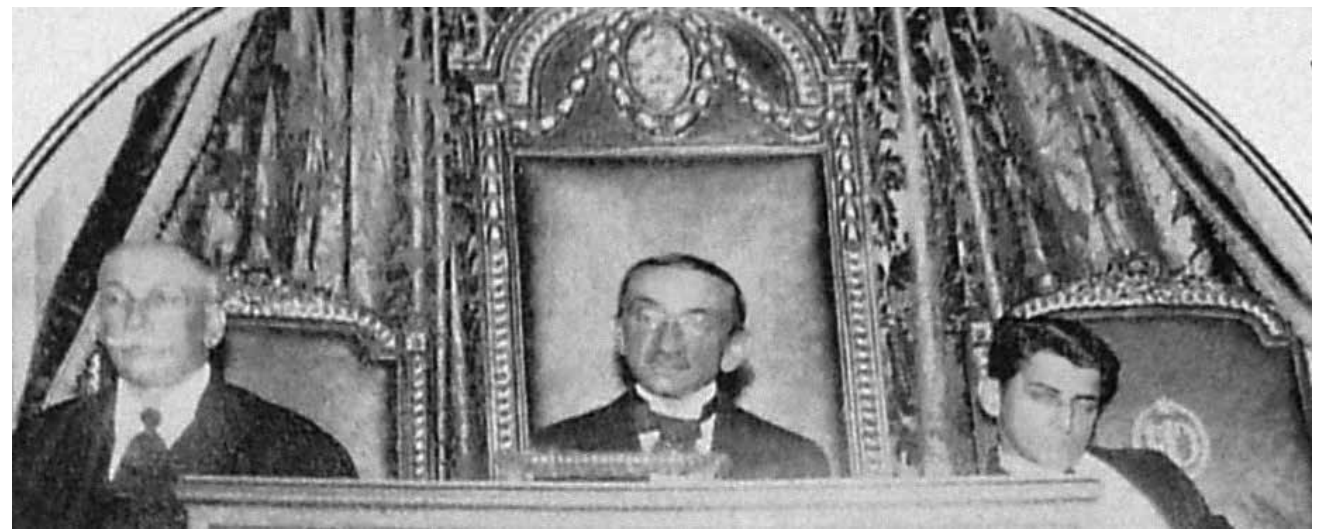

Figura 3 - Solenidade de abertura do Primeiro Congresso Regionalista na Faculdade de Direito do Recife, vendo-se Netto Campello (Diretor da Faculdade), Odilon Nestor e Gilberto Freyre. Congresso Regionalista do Nordeste. Revista de Pernambuco, Recife, a. II, n. 21 , abril de 1926, p. 63.

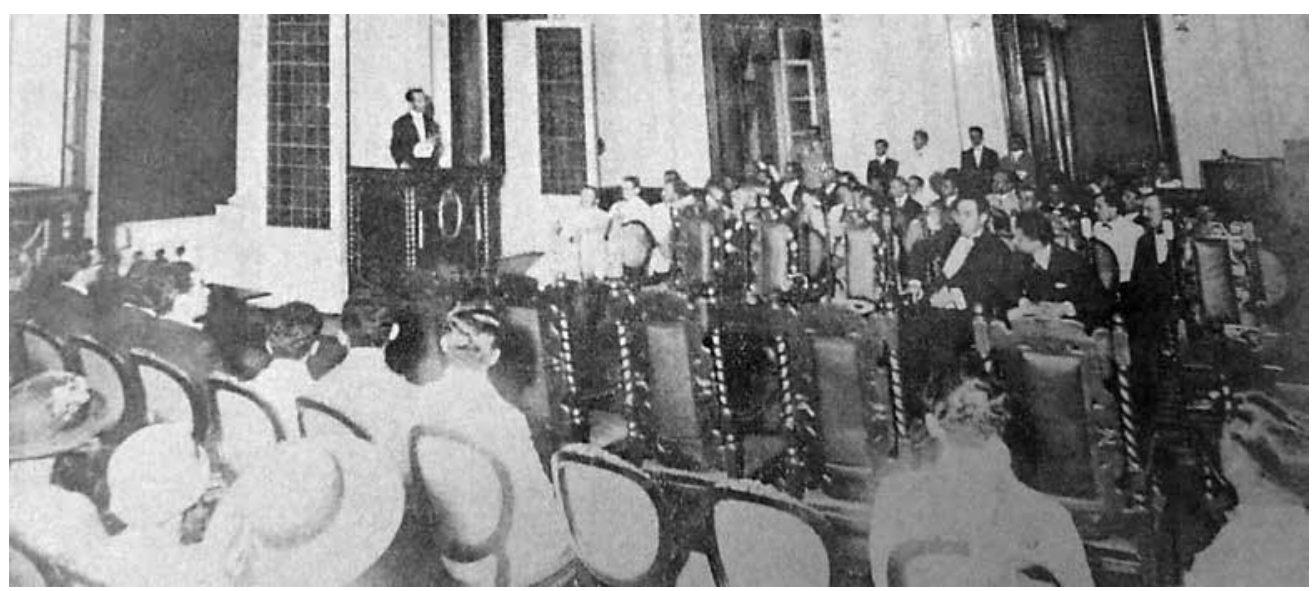

Figura 4 - Moraes Coutinho discursando na Solenidade de abertura do Congresso. Congresso Regionalista do Nordeste. Revista de Pernambuco, Recife, a. II, n. 21 , abril de 1926, p. 63. 
programa temático do evento era abrangente:

I - Problemas economicos e sociaes

1. Unificação economica do Nordeste. Acção dos poderes publicos e dos particulares.

2. Defesa da população rural. Habitação, instrucção, economia domestica.

3. $\bigcirc$ problema rodoviario do Nordeste. Aspecto turistico, valorização das bellezas naturaes da região.

4. $\bigcirc$ problema florestal. Legislação e meios educativos.

5. Tradições da cosinha nordestina. Aspecto economico, hygienico e esthetico.

II - Vida artistica e intellectual

1. Unificação da vida cultural nordestina. Organização universitaria. Ensino artistico. Meios de collaboração intellectual e artistica. Escola primaria e secundaria.

2. Defesa da physionomia architectonica do Nordeste. Urbanização das capitaes. Planos para as pequenas cidades do interior. Villas proletarias. Parques e jardins nordestinos.

3. Defesa do patrimonio artistico e dos monumentos historicos.

4. Reconstituição de festas e jogos tradicionaes. ${ }^{24}$

Esse programa revela os propósitos do centro. Pretendia conservar e renovar; valorizar características locais e as apropriar em um programa de reforma e conservação. Tinha em mente proteger a paisagem, a arquitetura do passado, a cultura e a identidade regional, assim como intervir, por meio de ampliação das vias de comunicação e de ações na economia, na habitação, na cidade, na educação e no intercâmbio intelectual e artístico. As teses encaminhadas ao evento versaram sobre temas diversos: questão florestal e rodoviária, integração econômica, festas tradicionais, jogos infantis, defesa do patrimônio histórico e da arquitetura religiosa etc. ${ }^{25}$ Entre as várias sugestões de encaminhamentos aprovadas, constava o envio de mensagens às autoridades eclesiásticas do Nordeste, solicitando conservarem nos novos templos "o caracter tradicionalista" e evitarem a destruição e remodelação das igrejas, realizando nelas apenas obras de conservação ou adequações indispensáveis à higiene. Constava, também, solicitar aos governadores a constituição de comissões encarregadas de zelar pela conservação de construções de interesse histórico e artístico; encaminhar aos
24. Centro Regionalista do... (1925b, p. 3).

25. Primeiro Congresso Regionalista... (1926c, p. 4). 
26. Primeiro Congresso Regionalista... (1926a, p. 3); Primeiro Congresso Regionalista... (1926b, p. 3); $1^{\circ}$ Congresso Regionalista... (1926a, p. 1); $1^{\circ}$ Congresso Regionalista... (1926b, p. 3); $1^{\circ}$ Congresso Regionalista... (1926c, p. 5).

27. Congresso Regionalista do... (1926, p. 26).

28. Freyre (1925c, p. 3). deputados federais pedido de apoio para a aprovação do projeto de lei apresentado pelo deputado pernambucano Luiz Cedro, visando à proteção do patrimônio histórico; sugerir às escolas realizar visitas de seus alunos a prédios antigos; propor a adoção de uniformes de brim branco como traje de rigor no Nordeste; e sugerir a arborização de ruas e jardins com vegetação típica da região e que os edifícios públicos adotassem o "estylo colonial". ${ }^{26}$

Freyre apresentou o trabalho "Esthetica e Tradições da Cosinha Nordestina" e Amaury falou acerca do "Estylo Colonial de Architectura do Ponto de Vista da Hygiene Moderna" e fez um discurso no encerramento do congresso durante um jantar ao ar livre, no terraço do DSA, onde foi servido peixe ao molho de coco, fritada de camarão, capão gordo, abacaxi, doce de caju em calda, queijo de coalho, água de coco, café de Bonito e licor de laranja. Nele, o médico identificou no trabalho do grupo reunido em torno do centro uma tenaz obra por "[...] um paiz com personalidade, com caracter, com alguma cousa de nitidamente nacional":

No nosso sentimento não ha nada de acanhado bairrismo, não ha pontos de vista politicos, não queremos nada reivindicar para nós, não queremos nos reservar nenhum direito que precise ser defendido dos outros brasileiros, nós temos um programma que é tanto nosso como deve ser de todo o Brasil.

Saiamos, portanto, tranquillos destas sessões. Tenhamos a certeza de que estamos trabalhando efficazmente, pelo Brasil, porque, eu estou certo, se os reaes interesses do paiz tivessem uma voz insuspeita e ella tivesse de deccidir entre os patriotas que vociferam pelas ruas, insultando os estrangeiros que nos são uteis e os que vivem, silenciosamente, modestamente, colhendo documentos historicos e conservando obras d'arte, collecionando receitas de bollos, aproveitando velhos azulejos, defendendo velhos portões e velhas arvores, reunindo, enriquecendo o folk-lore, seria para os ultimos as suas mais doces palavras, suas mais expressivas preferencias.

Srs. Congressistas: estes ultimos parece que somos nós. ${ }^{27}$

A referência ao bairrismo explica-se por toda essa movimentação ter sido acompanhada por suspeitas, na capital do país, de que se tratasse de uma conjuração. $\bigcirc$ discurso regionalista reivindicava o Nordeste como um Brasil mais autêntico, deixando claro o desconforto com a influência cultural do Rio e a disposição de resistir a ela. Logo cariocas - que deviam cultivar prevenções ao federalismo pernambucano do século XIX - interpretaram o movimento como uma conspiração e o acusaram de separatismo. Cobrado a esse respeito, Freyre argumentou que o centro visava "[...] colaborar na obra de integração brasileira, em vez de simplesmente repetir o que o Rio vem, nestes ultimos annos, repetindo dos peiores modelos extrangeiros". ${ }^{28}$ Amaury, no discurso ao final do congresso, 
buscou tranquilizar os cariocas apontando o grupo como "[...] uma associação sem regimentos ou regulamentos. É apenas um agrupamento de intellectuaes sob a presidencia de um poeta que vive inteiramente alheiado de interesses comuns e de politica". ${ }^{29}$ Definiu o regionalismo como "menos uma questão geographica que um sentimento de cousas nacionaes com as suas caracteristicas locaes" e descreveu o congresso como "uma semana de poesia e de cordialidade a serviço da unidade nacional". Sublinhou o papel da memória na construção dessa unidade e enumerou o que interessava ao centro conservar, guardar e reter:

Batalhando pela conservação dos nossos monumentos historicos; nossos costumes; de nossa arte colonial, incentivada e polida, nosso folk-lore, nós aspiramos dar ao Brasil o caracter que será, talvez, o maior passo para a unidade nacional.

Mostrando os encantos ingenuos do estylo colonial, nossa architectura urbana e rural, exaltando as receitas culinarias das quaes tanto garbo se fez no nordeste, revivendo os brinquedos infantis, realçando a poesia das lendas sertanejas, passamos os seis dias do Congresso, em cujas sessões tranquillas e simples, jamais se tentou fazer emulações separatistas e em cujos debates cordiaes os estreitos interesses locaes nunca tiveram interpretes. ${ }^{30}$

A diversidade de perspectivas e agentes comprometidos com a valorização de expressões da cultura local em Pernambuco durante aqueles anos é atestada por um conjunto de iniciativas não promovidas pelo Centro Regionalista, mas que atraíram seus sócios e/ou convergiram para alguns de seus propósitos. Poucos meses após a Semana das Árvores, um sócio do centro, Pedro Allain, apresentou um projeto de Código Florestal que foi discutido pelo Conselho Municipal em março de 1925. ${ }^{31}$ Em 1926 foi encenada no Recife a opereta regional "Aves de Arribação", com música composta pelo médico Valdemar de Oliveira e letra de Samuel Campello, mobilizando os temas da seca e do cangaço em uma narrativa que permitiu incluir o reisado e o carnaval. A Revista de Pernambuco, editada pela Repartição de Publicações Oficiais do Estado, abriu espaço aos temas regionais, divulgando o estilo neocolonial de arquitetura, publicando artigos sobre história local e registrando acontecimentos como a visita ao Recife, em 1926, de Luiz da Câmara Cascudo (figura 5). ${ }^{32}$ Houve uma investida resoluta contra cardápios importados e escritos em francês e um grande esforço de promoção da culinária regional, em almoços oferecidos em residências ou promovidos por iniciativa do governo estadual. A Exposição Geral de Pernambuco, organizada pelo governo do estado, nos últimos meses de 1924, celebrou a cultura e a história local, por meio de exposição de pinturas, leitura de contos, recitação de poemas, venda de comidas e apresentação de filmes,
29. O Regionalismo Como.. (1926, p. 2).

30. Ibid. (1926, p. 2).

31. Centro Regionalista do... (1925a, p. 1).

32. Revista de Pernambuco (1926). 
modinhas, violeiros, pastoril e "orchestra typica" regida por Nelson Ferreira executando músicas de compositores pernambucanos com temas regionais. ${ }^{33} \mathrm{~A}$ promoção do estilo neocolonial de arquitetura e o uso da flora local na arborização de ruas e jardins foram outras expressões desse movimento.

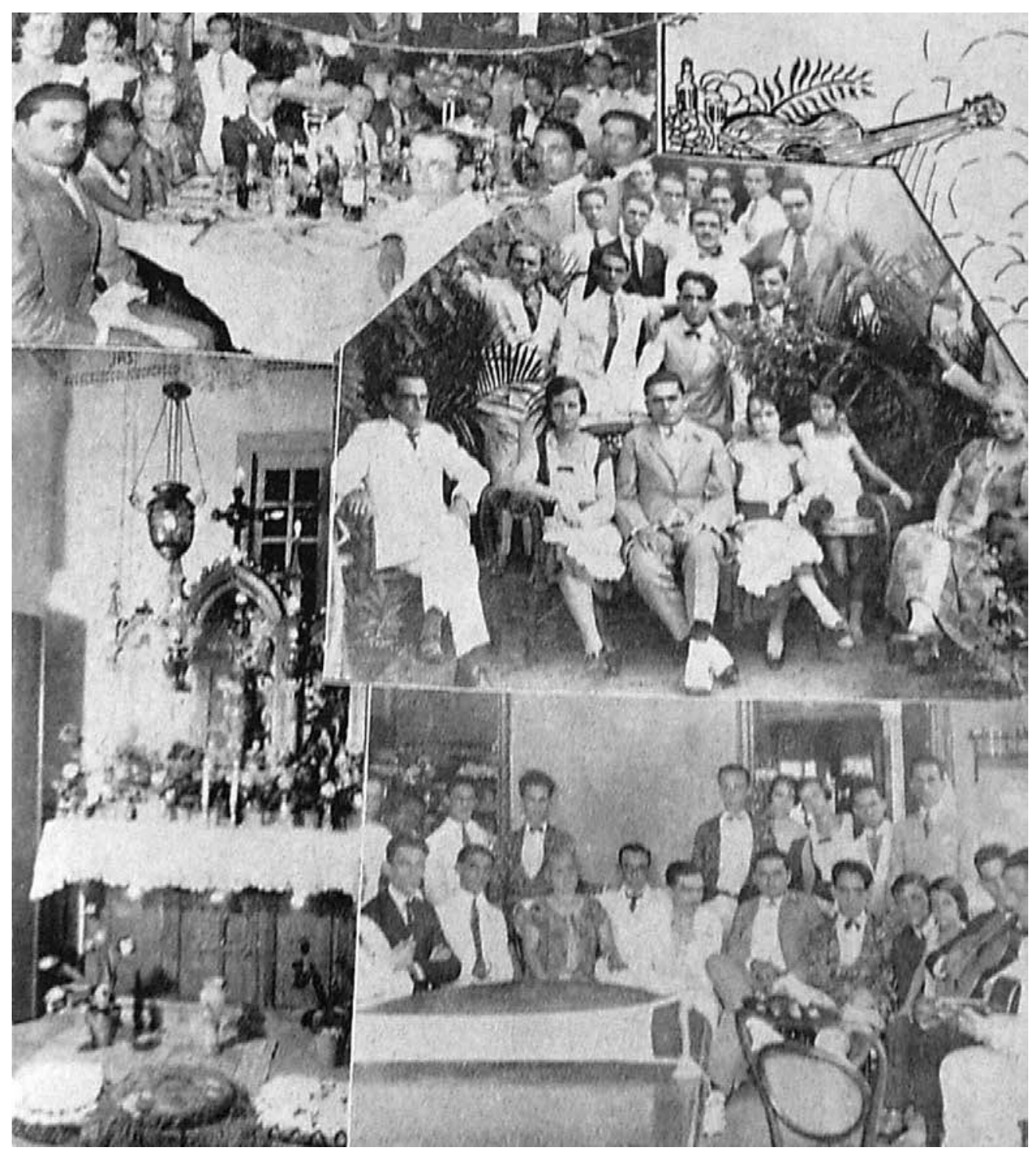

Figura 5 - Almoço oferecido a Câmara Cascudo, vendo-se, entre outros, o visitante sentado ao lado da esposa e filhas, Ascenso Ferreira, Góes Filho e seus pais, José de Góes (tio de Amaury de Medeiros) e Anna Cesar. Revista de Pernambuco, Recife, a. III, n. 23, maio 1926. 
O NEOCOLONIAL

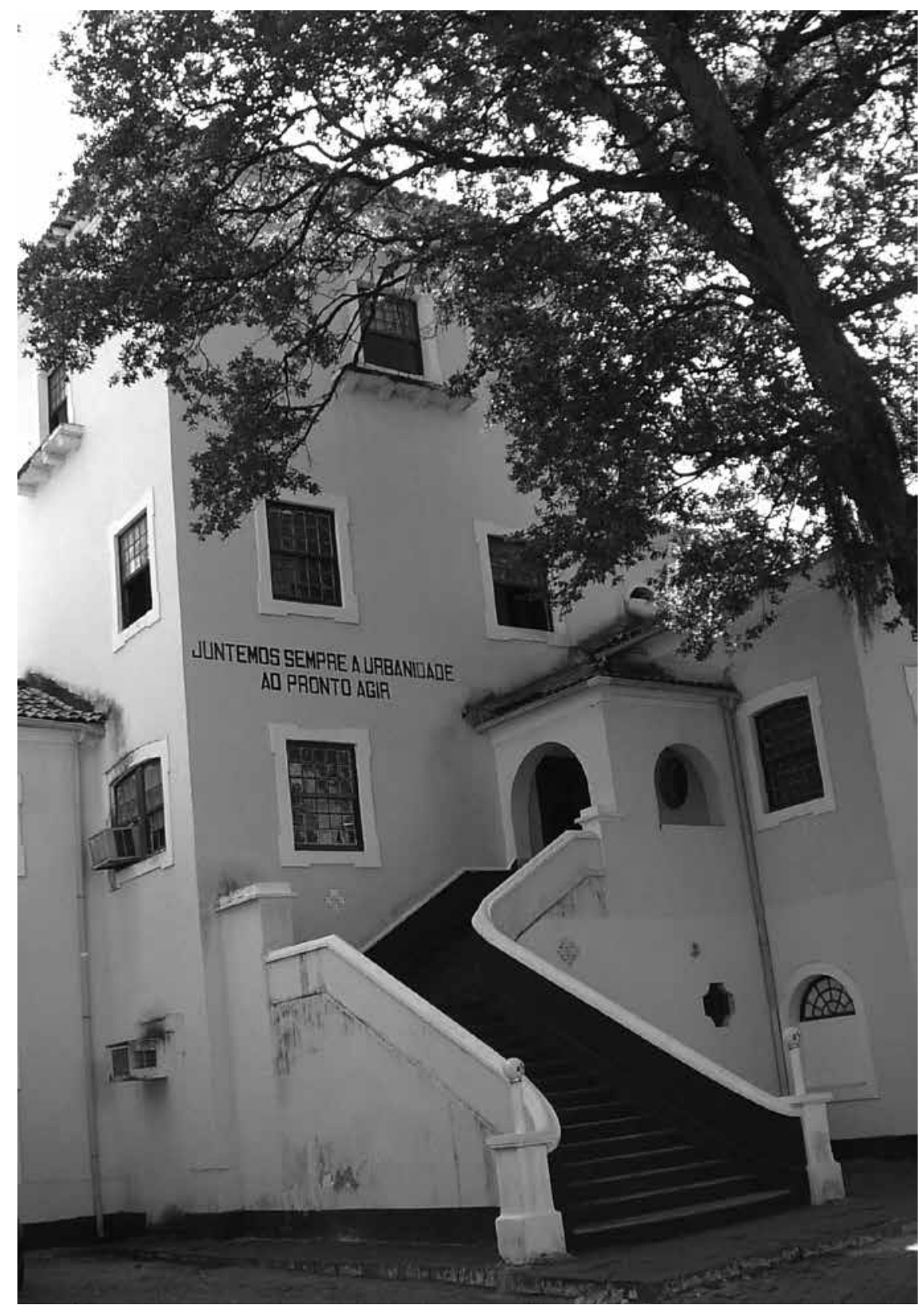

Figura 6 - Casa de Carlos Lyra Filho, na Rua Dom Bosco. Fotografia da autora, Recife, 2018. 
34. Marianno Filho (1924, p. 2).

35. Bello (1925, p. 2) e Fernandes (1926, p. 3).

36. Pinto (1926).

37. Freyre (1925c, p. 3).
Nas discussões promovidas entre regionalistas, a arquitetura e 0 urbanismo eram temas centrais. O sociólogo Gillberto Freyre, o jornalista Annibal Fernandes e o médico Amaury de Medeiros foram observadores atentos da arquitetura e da cidade do passado, sobre as quais - malgrado a ausência de formação específica - indicaram referências teóricas e projetuais, posicionaramse acerca de questões de forma e demonstraram desenvoltura no manejo do vocabulário referente à linguagem da arquitetura neocolonial.

No Diario de Pernambuco, em abril de 1924, foi reproduzido o artigo de autoria de José Marianno Filho, intitulado "Os Dez Mandamentos do Estylo Neo-colonial", que recomendava: não simular os materiais; usar formas "serenas e fortes", "que recortam a paysagem 'em massa', calmamente, sem contorções ou contrastes inesperados"; empregar a ordem toscana, trazida pelos jesuítas; paredes brancas, amarelo-camurça ou rosa e esquadrias verde-oliveira ou azul; discrição nos elementos decorativos; uso limitado de azulejos, óculos, coruchéus etc.; atenção à proporção e propriedades dos elementos, sem emprego de "apparatosa riqueza"; conciliar o estilo do passado com as exigências da vida moderna; "força estática da 'massa' architectonica" e "comprehensão do sentido dos elementos que the são essenciais"; e "uso da praxes tradicional". ${ }^{34}$

Enquanto isso, o Recife via erguerem-se casas em estilo neocolonial, duas delas tendo por proprietários Carlos Lyra Filho e Othon Bezerra de Mello e outras projetadas por Abelardo Gama, Georges Munier e Heitor Maia Filho (figura 6).

Sócios do Centro Regionalista - como Freyre, Julio Bello e Annibal Fernandes - sustentaram na imprensa uma discussão em torno das transformações em curso na cidade, denunciando a derrubada de árvores e a demolição de prédios antigos, assim como o aspecto banal da arquitetura que se erigia. ${ }^{35} \mathrm{O}$ historiador Estevão Pinto (1 8951968) publicou, na Revista de Pernambuco, o artigo intitulado "A Casa Brasileira", no qual faz uma eloquente defesa do "estilo colonial" e uma crítica severa aos rumos que estava tomando a arquitetura residencial nos subúrbios burgueses da cidade. ${ }^{36}$

Freyre defendia tomar a arquitetura do passado como fonte de referências - motivos ornamentais e soluções de projeto - para a do presente. No artigo "Regionalismo Creador", entendia que essas referências podiam ser buscadas tanto no tipo de "casa grande" de engenho, quanto em "[...] todo um mundo de sugestões interessantes (que) apodrece em velhos portões barrocos, umbrais meio pensos de jardins, janelas de varios typos, frontões, escadaria". ${ }^{37}$ Identificava um exemplo dessa possibilidade no projeto do Pavilhão de Caça e Pesca da Exposição de 1922, no Rio de Janeiro, concebido pelo arquiteto Armando de Oliveira. No artigo "Espirito e não estylo" assegurou que o Congresso Regionalista 
teria concluído que o "estylo colonial verdadeiramente se presta a toda a especie de construcção", embora discordasse de que se tratasse de um estilo:

O que nós possuimos é um espirito de casa, é uma linha de ingenua belleza de casa que se faz precisamente notar pelo a-vontade de suas desproporções e assymetrias, pelo seu cahir non-chalant para os lados. E nesse a-vontade de linhas se sente a hospitalidade, a simplicidade, a meio-rustica fidalguia da gente nordestina; e ao mesmo tempo a sympathia com o clima, com a paizagem, com o forte tropical, pelo desabar do telhado em pyramide e ás vezes irregularmente, plasticamente, como si fora um chapéu molle ou de Panamá. E são notas, suggestões, todas essas das quaes poderá tirar um architecto de talento e ao mesmo tempo de sensibilidade, o melhor dos partidos.

É por apresentar inconfundiveis qualidades e condições, não só de permanente sympathia com a paizagem e com o meio, como de plasticidade e flexibilidade - não sendo um estylo, não tendo a rigidez ou a definida systematização de um estylo - que o espirito colonial de casa me parece a suggestão mais rica, mais forte, mais pura, mais fecunda para o desenvolvimento de uma linha nossa, de um traço nosso, de uma expressão nossa, nas cidades do Brasil como o Recife, sahidas dos primeiros seculos coloniaes e ao mesmo tempo em contacto - contacto sempre a avivar-se, a intensificar-se - com as grandes actualidades commerciaes, industriaes, mecânicas. ${ }^{38}$

No Congresso Regionalista, Amaury apresentou o trabalho "Estylo Colonial de Architectura do Ponto de Vista da Hygiene Moderna", no qual unindo sua especialidade médica com seu gosto estético - negava a existência de conflitos entre higiene e arquitetura neocolonial - que tratava como "architectura tradicional" e "estylo colonial" -, concluindo que:

1 - Não há nenhuma incompatibilidade entre o progresso social e a architectura tradicional.

2 - Sob o ponto de vista da hygiene da habitação o estylo colonial pode adaptar-se a todas as exigencias das modernas leis sanitárias.

3 - Sob o ponto de vista do conforto moderno o estylo colonial pode receber sem prejuizos todos os aperfeiçoamentos da civilisação.

4 - Sob o ponto de vista da esthetica o estylo colonial é uma reação necessaria contra o máo gosto das construções sem caracter que tem mudado a physionomia das nossas cidades.

5 - $\bigcirc$ estylo colonial se presta a todos os edificios, residenciais, hospitais, escolas, igrejas, etc.

6 - $\bigcirc$ movimento em favor da architectura tradicional está ficando victorioso nos principaes centros de cultura nacionaes. ${ }^{39}$ 
Ao conceber um demonstrativo das visitas domiciliares realizadas pelo "serviço de polícia das habitações" do DSA, Amaury as representou por meio de uma fachada de casa. No desenho, adotou o modelo de moradia e de arquitetura que postulava: aquele que conciliava a inspiração em formas e motivos do passado com requisitos de higiene e de privacidade que o médico julgava essenciais. Assim, a fachada adota motivos da arquitetura do período colonial, como cercaduras e ornatos sobre os vãos que sugerem volutas. Da arquitetura rural do passado, o desenho recupera o telhado de quatro águas, dotado de beiral. O formato da coberta e a presença de beirais laterais indicam que - ao contrário das casas urbanas do passado - são residências separadas das construções vizinhas e dotadas de janelas nas laterais. As janelas e portas amplas e providas de vidros e venezianas completam este projeto de moradia neocolonial higiênica, fartamente iluminada e ventilada (figura 7).

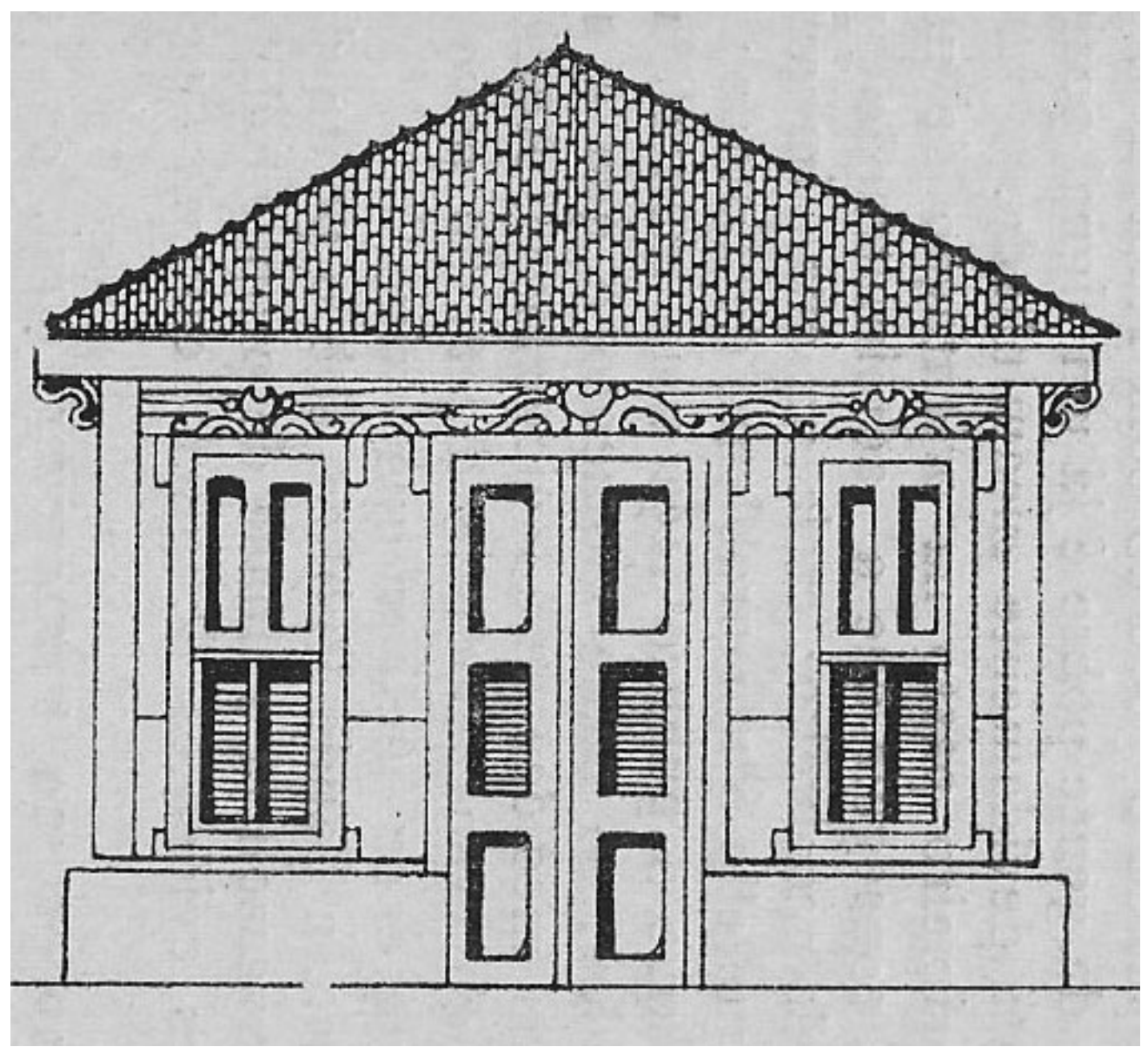

Figura 7 - Desenho no livro Saúde e Assistência. Medeiros, 1926a, p. 327 
Amaury não se limitou a defender o neocolonial em discursos e escritos. Sua posição na máquina estatal deu-lhe oportunidade de promover a construção de alguns prédios públicos seguindo o estilo. Contudo, foi além: ousou projetar. Ao relacionar prédios erguidos no Recife aproveitando as sugestões da arquitetura local, Annibal Fernandes incluiu o "Grupo Escolar de Afogados [...] e varios pavilhões annexos aos hospitaes do Recife [construídos] sob a orientação do director do Departamento de Saude de então, dr. Amaury de Medeiros". 40 Há certeza de que Amaury projetou o prédio que abrigou o grupo escolar e é grande a possibilidade de que também os prédios para os hospitais, como parece sugerir a expressão "sob a orientação". Os projetos executivos e a construção desses prédios ficaram a cargo da Seção de Obras do Departamento Geral de Obras Públicas, onde vários profissionais se encarregaram dos desenhos, que receberam vistos dos engenheiros Massolim Wanderley e Teixeira de Mello. Amaury, se não foi o único projetista, colaborou ativamente na concepção desses prédios, em termos de programa e forma.

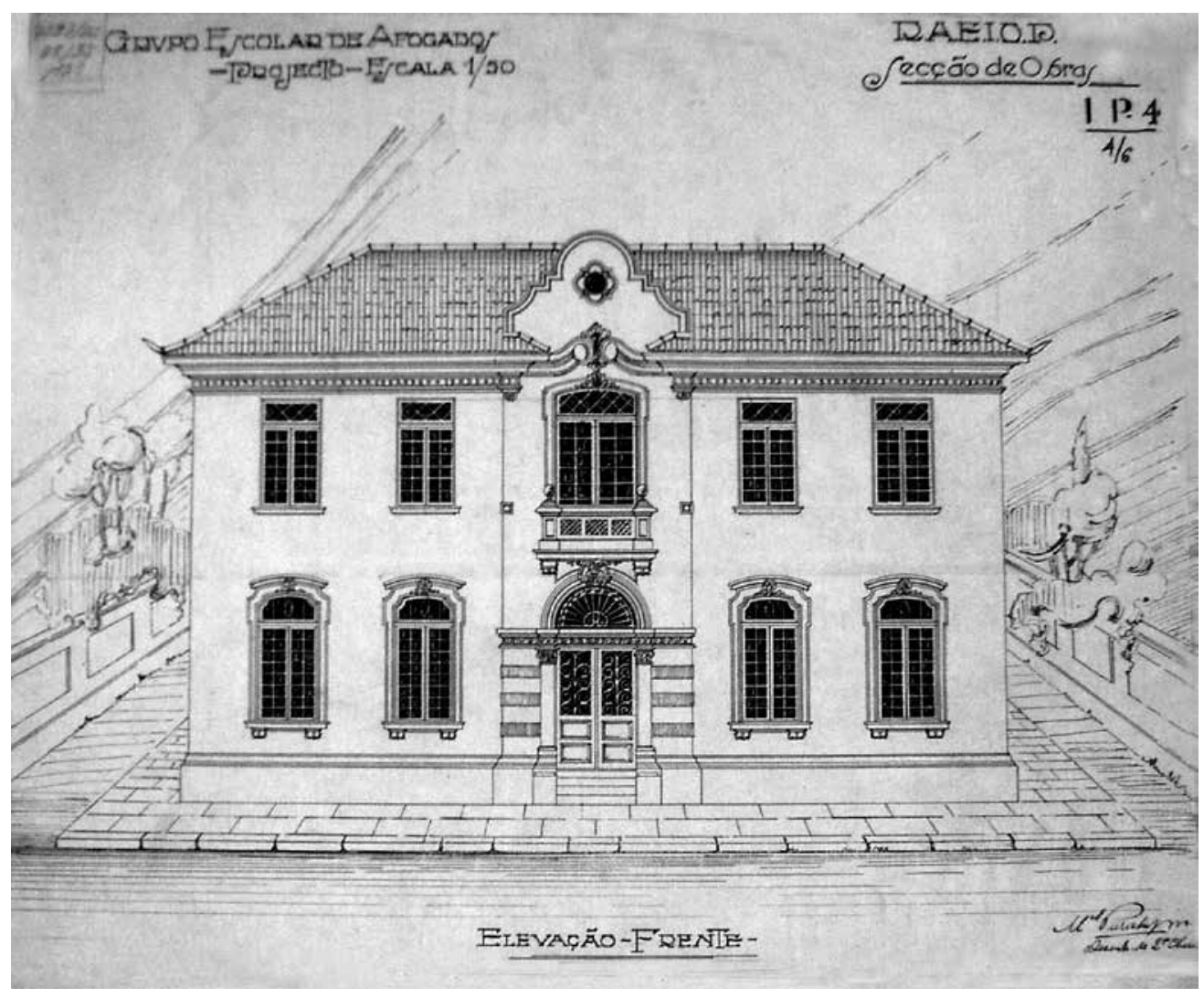

Figura 8 - Grupo Escolar Amaury de Medeiros. Projecto. Elevação Frente. DAEIOP - Secção de Obras. Escala: 1/50. Acervo do Arquivo Estadual Jordão Emerenciano. 
41. Governo que educa (1923, p. 1).

42. Medeiros (1926a, p. 124 e 126).

43. Dr. Sergio Loreto (1924a, p. 3).
Em junho de 1923 - quatro meses após sua posse no DSA - o Jornal do Recife publicou o desenho da fachada do Grupo Escolar Amaury de Medeiros. ${ }^{41}$ Esse era o projeto definitivo, cuja construção logo seria iniciada, permitindo que fosse inaugurado cerca de um ano depois, em outubro de 1924 (figura 8). O prédio, construído pelo governo do estado no bairro de Afogados, assim foi descrito por Amaury:

Darei noticias, especialmente, de um grupo escolar que se fez para servir de padrão ás futuras construcções do genero [...].

É uma escola com todos os rigores de hygiene escolar: orientação, illuminação, ventilação, pintura, etc. Tem bebedouros hygienicos, lavatorios e installações sanitarias proporcionados ás edades das creanças que frequentam o grupo, annexo ao grupo ha um edificio que se vê ao fundo onde funcciona o serviço medico e ha uma installação de banho para os escolares em cuja casa não ha banheiro. ${ }^{42}$

Além de definir os aspectos sanitários do prédio - cercado de vastas áreas ajardinadas e rodeada de janelas -, Amaury concebeu seus contornos formais. Ao inaugurar a escola, o então Secretário de Justiça e Instrução, Annibal Fernandes, esclareceu que fora Amaury

[...] quem me communicou a idéa da construcção de um predio escolar em espirito tradicionalista.

Foi elle que com seu esclarecido bom gosto e a sua elegancia intellectual me deu o plano e traçou o croquis que, como uma preciosa lembrança, elle acaba de me offerecer para que eu por minha vez o deixe sob a guarda dos professores deste grupo.

De tal alcance e de tal importancia social eu considerei a sua idéa, vendo triumphar aquella reacção de cultura durante certo tempo agitada por mim, como jornalista, que não hesitei em que a esta casa ficasse o nome do Director do Departamento de Saude, consagrando com seu prestigio e a sua autoridade, num edificio publico a arte tradicional por que tanto eu me batera.

Sempre considerei a anarchia architectonica no Brasil um indice desolador de ausencia de passado proprio, como si os povos não tivessem de evoluir dentro daquelle meio tradicional e local de que nos falla o distincto architecto Sr. Ricardo Severo e como si a architectura podesse fugir ás condições physicas e sociaes do meio. ${ }^{43}$

Em seu discurso, na mesma cerimônia, Amaury - com a falta de modéstia que o distinguia - tratou o prédio como uma lição de arquitetura, 
[...] como demonstração de que os edificios publicos, elevados com economia, devem primar pelo bom gosto antes que pelo luxo. [...] receberão aqui as crianças de nossa terra as primeiras revelações da eterna belleza nas linhas dessa graciosa architectura colonial. ${ }^{44}$

Após conferir a obra em fase de conclusão, no artigo intitulado "Um Consolo", Freyre não the poupou elogios:

[...] o edificio é todo um encanto: desde o telhado de beiral arrebitado á escada de pedra.

Que seja edificio official um edificio assim, com aquelle ar doce que logo ao primeiro contacto acolhe e encanta; que seja edificio official um sobrado que em tudo é tão nosso e de tão bom gosto [...].

Aos que teem edificios a renovar e a expandir, e não sabem como fazel-o dentro do typo de casa tradicional julgando-o inadaptavel ás exigencias da hygiene - convem uma visita ao grupo escolar de Afogados.

Eu já tenho passado por idiota por vir sustentando esta caturrice: que o Recife se póde renovar guardando a physionomia das casas e dos sobrados antigos, inclusive os de azulejos - esses azulejos que um illustre prefeito tanto perseguio.

O edificio do grupo escolar de Afogados vem reforçar meu ponto de vista. E reforçal-o no caso de edificios escolares, onde as exigencias modernas de hygiene são naturalmente mais numerosas e complexas que no caso de simples residencias.

[...] o edificio tem um ar amigo que ha de attrahir as crianças; e esse ar amigo muito maior será e mais doce, quando em volta á escola crescerem as arvores. ${ }^{45}$

Para Freyre, o edifício remetia ao passado "pelas vivas suggestões de belleza que elle nos oferece", sem deixar de se adequar às modernas regras sanitárias, qualidades que poderiam influenciar os rumos da casa burguesa recifense:

É possivel que o edificio do grupo escolar de Afogados sirva de contra vapor á nevrose que nos empolga de desprezar na architectura os motivos tradicionaes, aquelle typo de casa honesto e bom dos nossos avós, para seguir suggestões de cartões postaes e catalogos extrangeiros. ${ }^{46}$

Depois desse prédio, Amaury adotou o estilo neocolonial em pavilhões construídos nos hospitais Oswaldo Cruz e de Doenças Nervosas e Mentais. Nesses

\author{
44. Dr. Sergio Loreto \\ (1924b, p. 3).
}

45. Freyre (1924g, p. 3).

46. Id. (1924g, p. 3). 
47. Medeiros (1926a, p. 412 e 415). casos, não reivindicou a autoria dos projetos de arquitetura, mas não deixou de discorrer longamente sobre eles em seus discursos durante as inaugurações, com uma intimidade e autoridade que denunciam um grande envolvimento na concepção. Assim justificou a escolha do estilo, ao falar no Hospital Oswaldo Cruz:

Foram estes pavilhões, como os outros, que dentro em pouco inauguraremos no serviço de Doenças Nervosas e Mentaes, construidos em estylo colonial: estylo que pretendeu tomar velhos motivos decorativos, simples e alegres, que o snobismo havia abandonado e que vai, felizmente, se impondo a Justiça dos homens de bom gosto.

Eu sei que muitos preferiam que fossem elles construidos, talvez, em estilo mourisco, ou bysantino... A opinião pessoal é um respeitavel direito que nada pode cercear, nem mesmo no mais autocrata dos regimens, nos paizes mais disciplinados e, muito menos, em terras como as nossas, onde o nivel geral da instrucção é baixo e a educação social anda apenas esboçada.

Preferimos o estylo colonial, por ser mais de accordo com o nosso clima, mais simples, mais risonho e mais barato. ${ }^{47}$

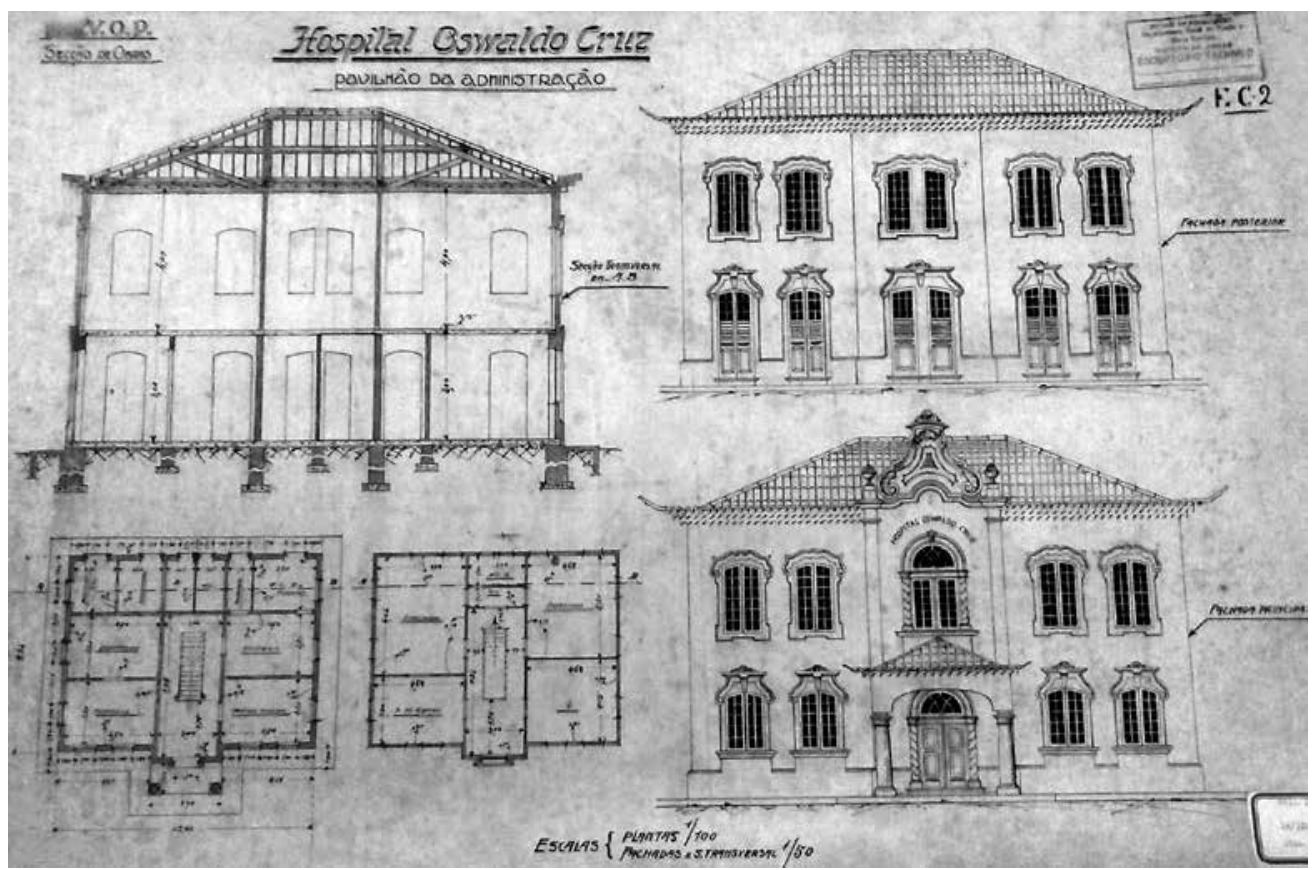

Figura 9 - Hospital Oswaldo Cruz. Pavilhão da Administração. DGVOP - Secção de Obras. Projecto. Escalas: planta, 1/100; fachadas e cortes, 1/50. Acervo do Arquivo Estadual Jordão Emerenciano.

Amaury sugeriu entender que as opções que se colocavam ao estilo neocolonial eram as várias tendências ecléticas. Comparando-os, no rebuscamento eclético enxergava esnobismo, enquanto no neocolonial via um estilo adequado ao 
clima e aos recursos disponíveis, mais simples e agradável. Colocando-se como nacionalista, esteta e gestor responsável de recursos públicos, sugeria ser sua opção arquitetônica a mais justa e aceitável por homens de bom senso e bom gosto.

O Pavilhão da Administração do Hospital Oswaldo Cruz foi recebido por Freyre com uma entusiástica descrição, que inclui cores e detalhes que as fotos antigas e as reformas posteriores apagaram (figura 9):

É ao meu vêr o mais lindo colonial novo que hoje possue o Recife. $O$ mais lindo, o mais suggestivo, o mais brasileiro, o mais pernambucano. Simples, forte, elegante, doce, franciscanamente hospitaleiro, todo claro e aqui e alli avivado pelos salpicos azues e amarellos de raro azulejo antigo; o telhado de beiral arrebitado, vivamente vermelho; jarros de Santo Antonio do Porto, no portico e dos lados, a aligeirarem a tranquilla simplicidade de edificio de uma leve graça heraldica. ${ }^{48}$

Freyre também aprovou os projetos dos novos pavilhões do Hospital de Doenças Nervosas e Mentais, que reputou "fortemente sympaticos". ${ }^{49}$ No discurso na inauguração do Pavilhão de Observações desse hospital (figura 10), Amaury sugeriu que o progresso da ciência fora acompanhado por uma degradação do gosto, que impunha recorrer às formas do passado:

Harmonioso e simples, na alegria suave de suas linhas coloniaes, elle nos recorda o bom gosto de nossos maiores; com todos os recursos da sciencia moderna, evolvida e segura, mais perto da verdade e mais longe do preconceito, elle é um exemplo do bom senso moderno e da bôa sciencia actual. Assim, está elle a dizer que nada impede que ao bom gosto de hontem se possa associar a bôa sciencia de hoje.

Olhae para o edificio; sua fachada clara, onde os motivos coloniaes revivem e sorriem, não lembra, nem de longe, a dureza dos carceres, nem as angustias dos hospitais.

Aqui, tudo procura esconder e mitigar o mal-estar e o desespero dos que vão entrar, e a dorida tristeza dos que vão ahi deixar aquelles a quem amam.

Não ha nem pezadas grades de presidio, nem as côres tristes dos antigos nosocomios; tudo disfarça a dôr e a diminue.

Existem azas de andorinhas estilizadas nos beiraes, ingenuos e alegres azulejos, pateos calmos, jarros de flores, tudo a suggestionar alegria e esperança, tudo a prometter cura, tudo a confortar os que ficam e os que passam... 50

Nesse conjunto de prédios retomaram-se motivos e formas do passado, em construções modernizadas pelos novos materiais, pelo atendimento a demandas de higiene e por programas e arranjos coerentes com as diretrizes terapêuticas e 
pedagógicas adotadas pelas instituições. Utilizou-se alvenaria de tijolos, ferro, vidro, piso de cerâmica e revestimento em azulejo. As construções foram implantadas em meio a áreas verdes, para as quais abriam suas sequências de amplas portas e janelas, guarnecidas de caixilhos de vidros, venezianas, grades e bandeiras vazadas de ferro. As referências à arquitetura do passado se revelaram na volumetria, no telhado e nos motivos ornamentais. São prédios compostos por um único volume, com ornamentação concentrada em torno das janelas e do acesso principal, com compromissos com a simplicidade e discrição de uma arquitetura de grandes lanços de paredes nuas e telhados singelos de telhas de barro, seguindo a vertente do neocolonial postulada por José Marianno.

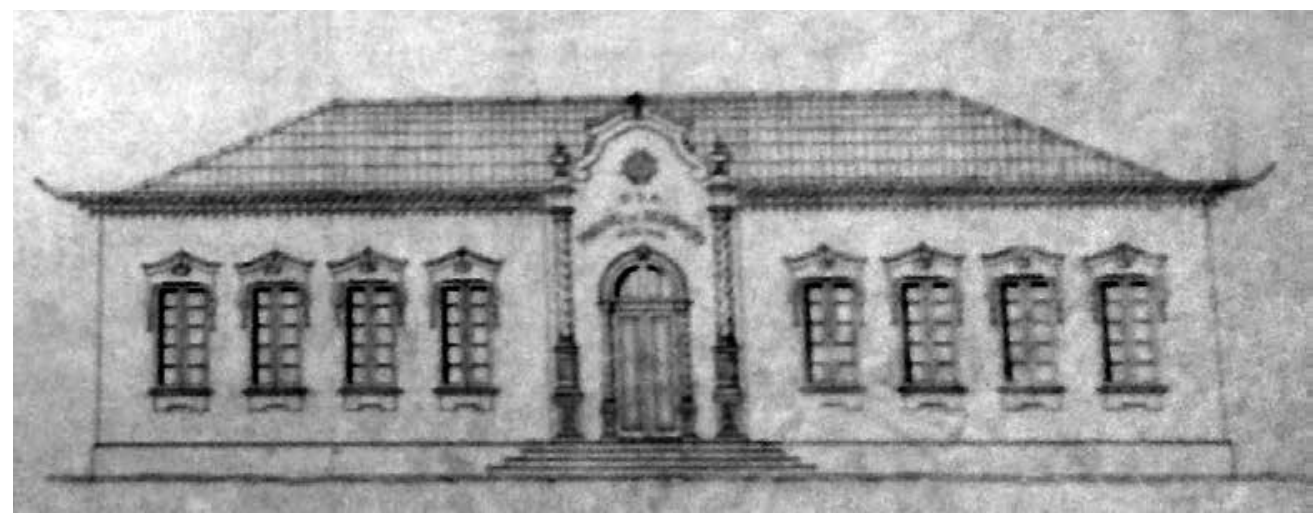

Figura 10 - Pavilhão de Observações. Hospital de Doenças Nervosas e Mentaes. DGVOP - Secção de Obras. Projecto. Elevação. Escala: 1/50. Acervo do Arquivo Estadual Jordão Emerenciano.

Não é de estranhar que Amaury tenha sido vivamente saudado por Freyre, cerca de um mês após as inaugurações dos prédios dos dois hospitais, em artigo cujo interesse para a compreensão da "batalha" que se travava no campo da arquitetura no Recife justifica uma longa citação:

Deste serviço de claro e bom gosto á cidade do Recife póde estar seguro o sr. Amaury de Medeiros: o de vir animando a edificação publica, principalmente no seu departamento, de um sentido de belleza que andava lamentavelmente esquecido ou deliberadamente desprezado nos esforços desse genero. Um estrito utilitarismo o havia posto de lado. 
Porque o certo é que pelo Brasil toda a victoria republicana, excitando improvisos de fortuna, posição, poder; trazendo á tona novos-ricos, novos-cultos, novos-poderosos fez correr uma onda facil, suja, grossa de mau gosto, de "restacuerismo" e desse utilitarismo que vê nas preoccupações de belleza uma frivolidade.

A documentação está ahi - nos edificios e nas estatuas, nos monumentos, nos tumulos, nas reformas. São edificios, palacios, monumentos, estatuas que accusam uma pobreza de gosto que espanta e entristece.

No Recife, ahi está, por exemplo, a ganhar em mau gosto a toda a ramalhuda architectura bancaria e commercial, com seu mercuriosinho clownesco, irmão do de Chora Menino; a ganhar a distancia e com vantagens de campeão irrivalisavel o "Grand-Prix" de Mau Gosto - o edifício da Fiscalização Federal do Porto. O ridiculo de suas enormes bolas e o absoluto desconforto interno ficarão entre os documentos mais vivos e mais emphaticos do mau gosto que no Brasil se apossou de uma geração de realizadores com a furia duma horrivel doença. Duma horrivel doença que é como bexiga em ponto grande - deixando na physionomia das cidades suas tristonhas marcas.

Contra esse passado immediato de mau gosto e estreito utilitarismo é que a nova gente do Brasil precisa reagir, alliada com o Grande Passado brasileiro, rico de suggestões a desenvolver nos esforços criadores de hoje.

E aos que desejamos um Pernambuco que se renove pernambucanamente dentro do espirito do seu passado vivamente romantico e das suggestões de sua paizagem, deliciosamente tropical - animam-nos de um vivo prazer esforços como os do sr. Amaury de Medeiros.

O novo pavilhão do Hospital Oswaldo Cruz vem accrescentar á reacção do bom gosto no Recife uma victoria que muito merece ser sondada e destacada. ${ }^{51}$

Acima, Freyre assinala os setores bancário e comercial como os principais representantes da burguesia ascendente, dominada pelo mau gosto e por uma abordagem utilitarista da arquitetura. No Recife, o bairro portuário - sede desses setores do capital - era o lugar onde esse gosto duvidoso se expressava com todo vigor que os cálculos econômicos permitiam. Lá, o "mercuriosinho clownesco" elevava-se na sede da Associação Comercial (figura 11 ) e o prédio da Fiscalização Federal do Porto, agraciado com o "Grand-Prix de Mau Gosto", ostentava suas inexplicáveis grandes "bolas" de cimento (figura 12).

Como se não bastassem suas formas controversas, os dois prédios eram resultantes da reforma do bairro, tantas vezes lastimada por Freyre. 
Figura 11 - Prédio da Associação Comercial, com seu "mercuriosinho clownesco" equilibrando-se no alto da fachada. Illustração Brasileira. Rio de Janeiro, a. V, n. 46, junho 1924.

Figura 12 - Bairro do Recife, vendo-se o edifício que abrigou na década de 1920 a Fiscalização Federal do Porto do Recife, com suas "enormes bolas". Acervo do Museu da Cidade do Recife.
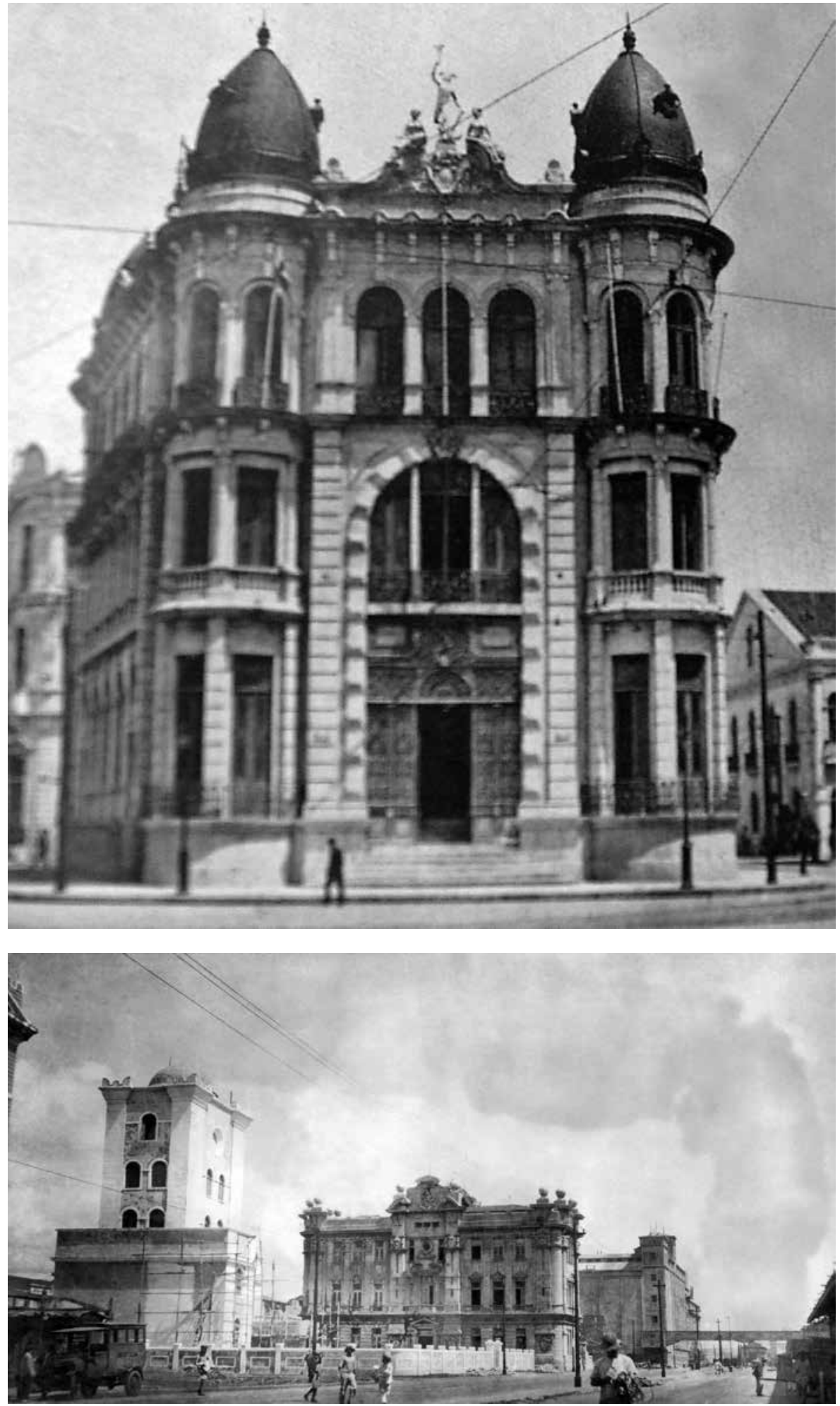
Uma característica do grupo de adeptos do estilo neocolonial, reunido no Centro Regionalista, foi um forte sentido conservacionista. No Recife não houve casos notórios de emprego de material retirado de prédios antigos remodelados ou destruídos - em construções novas ou em reformas de viés neocolonial, exceto o uso - muito comedido - de azulejos antigos.

Tal atitude explica-se quando, como lembrou Annibal Fernandes, o principal estímulo para a eclosão do movimento regionalista foi a reação "contra a destruição systematica do nosso patrimonio artístico" ${ }^{52}$ Reagia-se às reformas urbanas e arquitetônicas, impulsionadas pela igreja e pelo estado nas primeiras décadas do século XX, que destruíram lugares de grande relevância no passado da cidade. A igreja, entre outras coisas, encarregou-se de desfigurar a Sé de Olinda e o que restava do engenho Casa Forte, por meio de projetos de viés neogótico concebidos pelo arquiteto Rodolfo Lima (figura 13). Entre 1909 e 1913, por iniciativa do governo estadual, reformou-se o bairro do Recife, com grandes demolições e alteração do sistema viário que substituiu pátios, becos e ruas por avenidas ladeadas por prédios de arquitetura eclética. Em 1922, por iniciativa do governador Jose Bezerra, o Palácio do Governo passou por reforma, que acrescentou um pavimento e o privou de sua feição neoclássica.

A crítica à destruição dos lugares e da arquitetura do passado foi um tema recorrente nos artigos publicados por Freyre nos anos vinte. Em "Physionomia das Novas Cidades", censurou a destruição dos arcos de Santo Antônio e da Conceição e do Cais da Lingueta e as demolições da cidade antiga em "louvor das avenidas novas, dos prédios novos, da architectura nova, da esthetica dos engenheiros". Lastimou que "a moda dos frontões, feitos a molde", estivesse substituindo "as telhas formando no beiral cornos de lua; com as biqueiras tão caracteristicas do Recife". Afligiu-se com a marcha dessa "moda" em direção ao interior: "[...] nessas cidadesinhas avanços falsamente civilizadores teem levado e continuam a levar o horrivel da architectura de confeitaria, victoriosa nas capitaes. Victoriosa no Recife - donde já desappareceu tanta cousa interessante". Defendeu a necessidade de resistir "contra este haussmannismo estupido [...] para que não desapareça de todo das nossas cidades a expressão da nossa vida e do nosso espirito". Previu que o Congresso Regionalista, que aconteceria meses depois, "[...] realizará, com relação a este assumpto, a obra de educação que já devia ter sido iniciada. É um relógio despertador que retine atrasado. Mas, em tempo, ainda, de despertar vontades, sentimentos, forças dispersas". Deteve-se, também, na apreciação de qualidades de espaços urbanos e casas do passado. No antigo 
53. Freyre (1925a. p. 3).

54. Id. (1926e, p. 1).

Figura 13 - Matriz da Casa Forte, anos após a reforma do início do século XX. Fotografia da autora, Recife, 2018.
Cais da Lingueta, lembrou as frondosas gameleiras protegendo do sol os bancos de ferro e os velhos sobrados, hotéis e bodegas. Entre os méritos das velhas casas de engenho, salientou a cobertura: "[...] o typo tradicional de telhado em pyramide, cahido sobre pilares, é exactamente o que melhor corresponde ao nosso clima e aos nossos hábitos de vida". ${ }^{53}$ No âmbito da forma urbana, postulou conciliar no Recife "as ruas estreitas, de doces sombras; ruas quase mouriscas; ruas camaradas da gente" com a necessidade de "largos espaços para o trafego pesado". Recusou sacrificar "[...] a nenhum haussmannismo o delicioso a-tôa ou a-vontade de certas velhas ruas do Recife, formando cotovelos". Criticava "[...] a esthetica de fraque querendo tudo recto, plano, direito, com sacrificio até de velhas egrejas". ${ }^{54}$

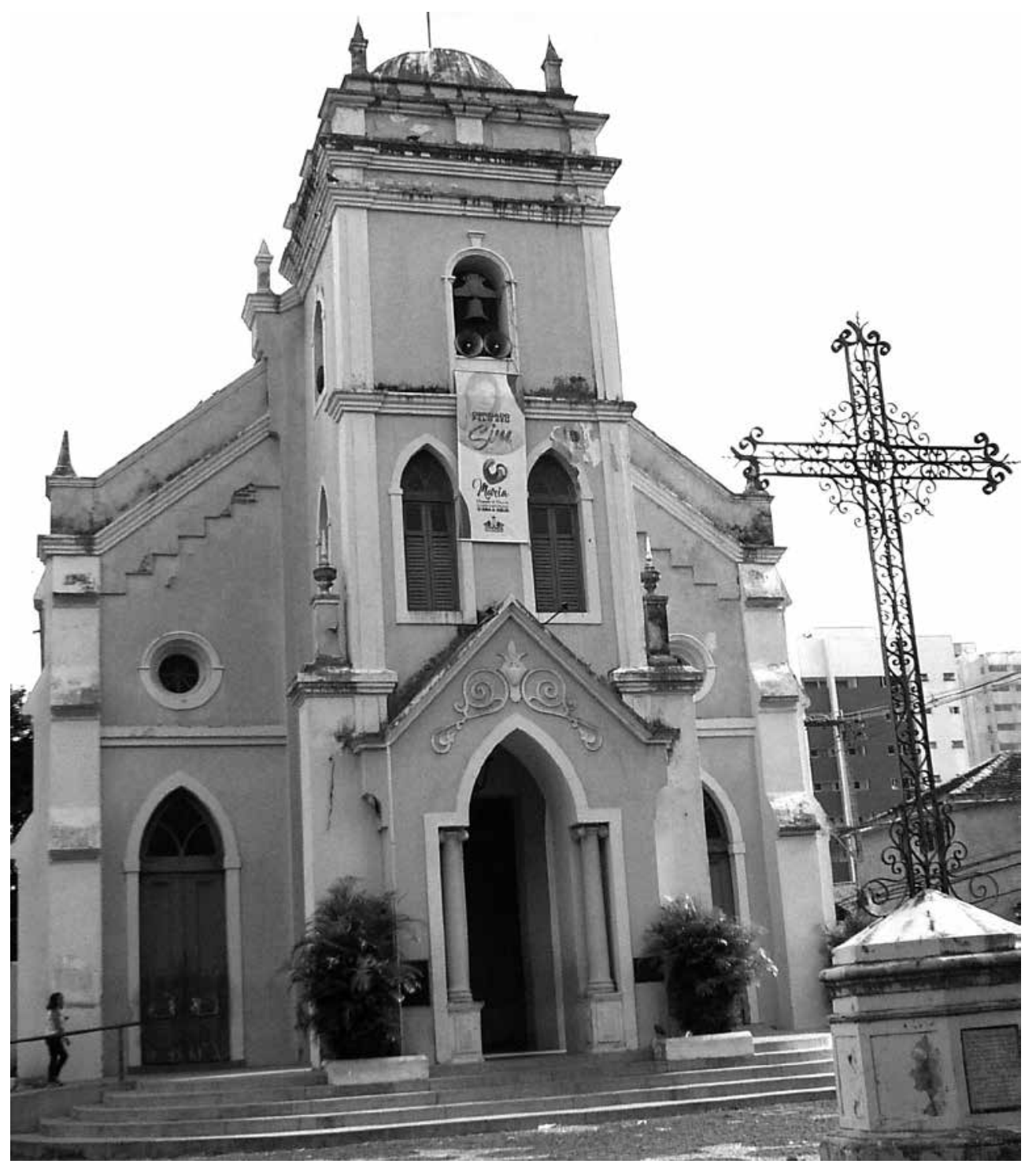


Contudo, o respeito pela cidade do passado era, entre os regionalistas, um tema delicado, fadado a contrapor os médicos sanitaristas a outros membros do centro. Fiéis ao higienismo, Octavio de Freitas e Amaury, em vários escritos, não pouparam de críticas os bairros antigos e as características do sítio onde o Recife surgira.

Octavio de Freitas vinha insistindo em suas críticas ao Recife antigo desde o início do século. Em 1904, em "Os Nossos Médicos e a Nossa Medicina", repudiou o "máo gosto" do bairro de São José e elegeu o bairro portuário - pela falta de conveniente aeração de ruas e construções - como um dos problemas sanitários da cidade. Sua crítica ia além da higiene: deslizou para a estética, mirou os administradores públicos do presente e condenou seus antecessores. Apontou os portugueses como a fonte dos "erros" e "desordens" da cidade. Contrapôs o bairro portuário por eles fundado ao "inicio intelligente" de Santo Antônio, traçado pelos holandeses, com ruas largas e arquitetura renovada. Recorreu à Alfama como indício dessa inaptidão lusitana:

Para aquilatar do adiantamento sanitario de uma localidade qualquer, o primeiro facto que fere a attenção do observador é o traçado geral de sua edificação.

Sentir-se-hia embaraçado, certamente, em dar opinião favoravel a respeito de nossa salubridade, quem procurasse emitill-a baseada neste conceito e tendo sommente em mira o Recife antigo que conservamos em grande parte tal como nos legaram os nossos antepassados.

De facto, até bem pouco tempo as nossas construcções não possuiam architectura alguma, sendo as casas edificadas atabalhoadamente, sem arte e sem esthetica.

Parece que a preoccupação exclusiva dos nossos avoengos era poupar terreno, pouco se importando que isto désse em resultado ficarmos com uma cidade sem belleza e sem hygiene.

Um rapido passeio pelo bairro de S. Frei Pedro Gonçalves do Recife, todo quasi constituido por viellas estreitas amontoadas de casarões com multiplos andares, onde a luz e $\mathrm{o}$ ar não poderão circular livremente e em abundancia, basta para hesitarmos em nos definir se somos a Veneza americana ou o representante genuino do bairro do Alfama da antiga Lisboa.

É justo, pois, criminar os nossos antepassados pela falta de aformoseamento de varios pontos desta capital e censurar os nossos contemporaneos por não quererem endireitar e reformar o que torto e defeituoso encontraram.

A picareta faria um beneficio incalculavel, si, empunhada por mão segura e amestrada, destruisse muita coisa ruim que possuimos, alargando ruas, abrindo avenidas e construindo casas confortaveis de accordo com os preceitos da hygiene moderna..$^{55}$

E assim foi feito. Pouco depois, entre 1909 e 1913, o bairro do Recife passou pela reforma reclamada que seria, anos depois, lastimada por regionalistas. 
56. Id. (1910, p. 49).

57. Id. (1910, p. 55-56).

58. Id. (1919, p. 5-6).
Associadas a uma remodelação do porto, grandes demolições - inclusive a da igreja do Corpo Santo e dos arcos de Santo Antônio e da Conceição - abriram espaço para avenidas e para prédios de arquitetura eclética (figuras 14 e 15). Com a autoridade iá conquistada nos meios médicos recifenses, Octavio de Freitas não pode deixar de ser considerado um dos mentores dessa reforma. Sua fala no Primeiro Congresso Médico de Pernambuco, em 1909, saúda com entusiasmo o início das "[...] obras do porto que alviçareiramente já nos annunciam estes melhoramentos para o bairro do Recife, num recente edital de trezentas e quarenta desapropriações". 56 O alargamento e a arborização de vias e as medidas para um maior controle das condições de higiene das novas construções permitiram a Freitas ver nessas ações indícios de que a cidade estava disposta a pôr cobro às "heresias sanitarias" que vinha acolhendo ao longo de sua história:

Felizmente parece que vamos entrar em bom caminho e que o nosso adorado Recife será, em breve transformado numa cidade de primeira ordem, num centro de edificações modernas, como elle tem direito, pelas suas bellezas naturaes, tão fartas e variegadas. ${ }^{57}$

Apesar dessa "vitória", suas críticas à cidade antiga foram retomadas em trabalhos posteriores. Em 1919, em relatório apresentado ao secretário-geral do estado, Freitas voltou a insistir que à inadequada condição sanitária do Recife teriam contribuído o "terreno de péssima contextura" - mangues, pântanos, quase ao nível do mar e com lençol freático próximo à superfície - e a ação de seus construtores:

[...] os seus povoadores ainda mais aggravaram a precaria situação sanitaria da cidade edificando as suas casas sem ar e sem luz, umas amontoadas sobre as outras e todas as ruas tão estreitas que mais parecem viellas escuras e beccos sem sahidas. ${ }^{58}$

Amaury, anos depois, uniu-se a Octavio de Freitas nessa crítica de viés sanitarista às heranças do passado no Recife, em escritos sobre higiene das moradias. A habitação era um tema que não podia deixar de criar tensão entre os sanitaristas e outros regionalistas. As casas antigas dos bairros centrais do Recife, onde Freitas identificou um "amontoado de heresias sanitárias", foram referidas por Amaury como "casa-matadouro", "casa-túmulo" e "casa-gaveta". Para ambos, conciliar a leitura higienista da cidade do passado com o credo regionalista não foi tarefa fácil. Em reuniões do Centro Regionalista, não deve ter sido cômodo para Freitas ouvir as inescapáveis críticas à reforma urbana do bairro do Recife, que reivindicara e apoiara. 


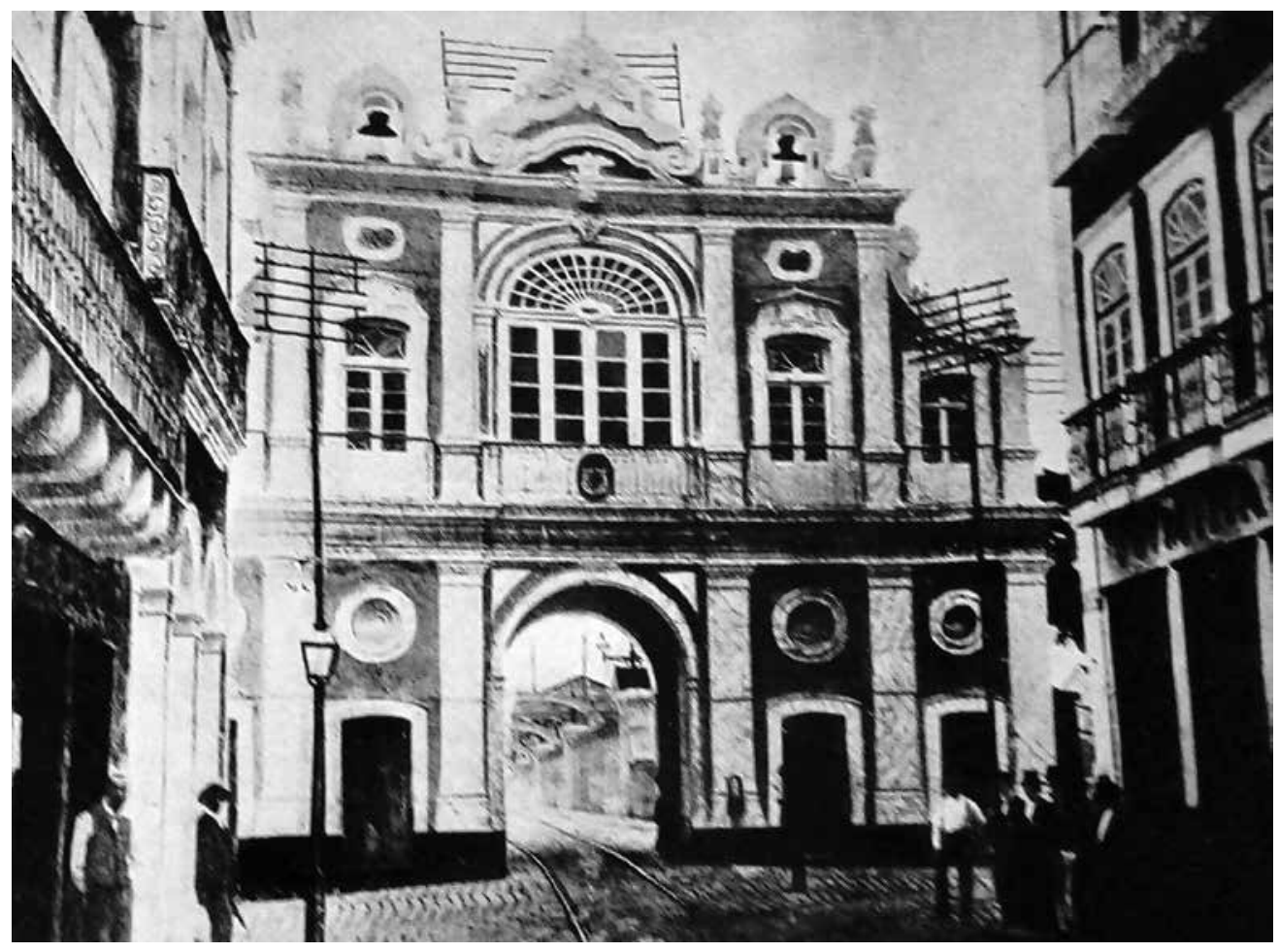

Figura 14 - Arco da Conceição, demolido nas obras de reforma do bairro portuário do início do século XX. Illustração Brasileira. Rio de Janeiro, a. V, n. 46, junho 1924.

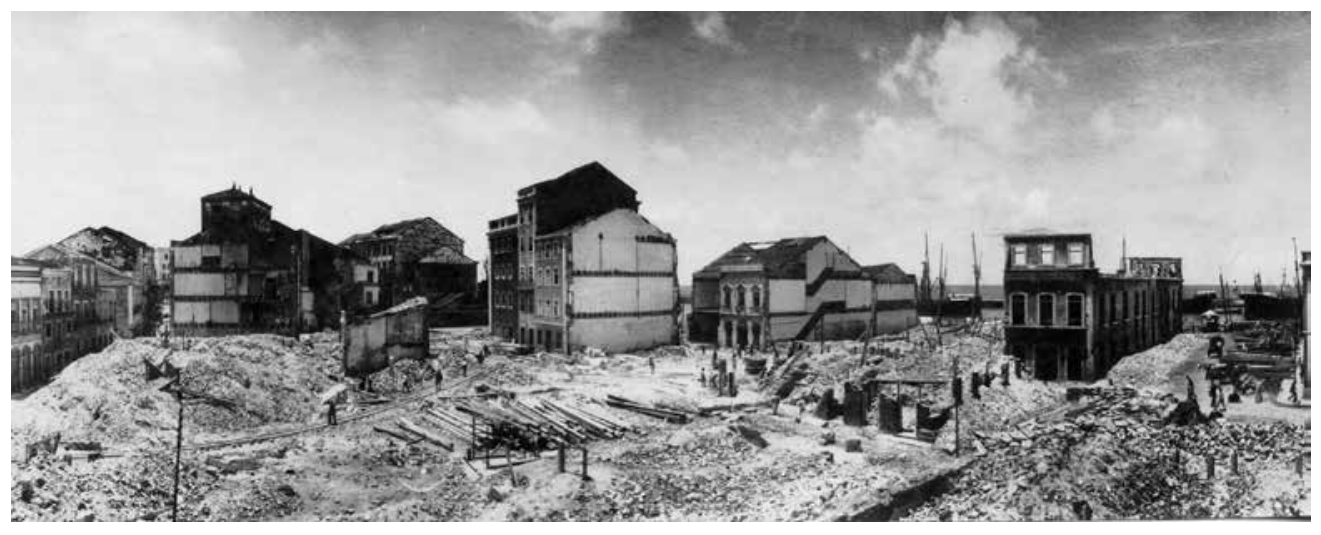

Figura 15 - Reforma do Bairro do Recife. Acervo do Museu da Cidade do Recife.

Em Amaury não incidiam "culpas" do passado, mas o dilema presente de conciliar a higiene e a cidade herdada. Comparadas às posições de Gilberto Freyre, as suas eram mais restritivas quanto ao que conservar do passado e quanto ao que dele recuperar como referência para a arquitetura do presente. 
59. Medeiros (1926a, p. 326).

60. Freyre (1923a, p. 3).
Sua formação médica e posição de diretor do órgão de higiene colocavam-no em uma situação muito complicada, frente à arquitetura e aos espaços urbanos do passado. Era-the muito difícil esquivar-se de considerar a relação estabelecida pela medicina entre moradia e doença. Como especialista em doenças de pulmão associava umidade com a tuberculose; como sanitarista, vinculava alcova com proliferação de epidemias. Insistia na crítica à "casa sem janelas", que correspondia, no Recife, à maioria das moradias dos bairros antigos centrais. Sua admiração pela história, cultura e natureza local terminava onde começava a "moderna ciência da higiene". Admirava a feição e os motivos ornamentais da arquitetura do passado, mas não estendia seus méritos ao interior das casas, nem às ruas estreitas onde se acomodavam. Da mesma forma, sua valorização da cultura local não incluía aqueles "preconceitos" que julgava comprometerem a saúde e atrapalharem as medidas que considerava úteis para promovê-la. Venerava a floresta e a natureza tropical, mas nem por isso "perdoava" lagoas habitadas por larvas de mosquitos e pinhões protetores de "mau olhado" em jardins. Sua opinião francamente desfavorável ao casario antigo que sobrevivia nos bairros centrais da cidade - sobretudo em São José - e sua aprovação às reformas urbanas do início do século XX, que destruíram grande parte desse casario no bairro portuário, foram reafirmadas no livro Saúde e Assistência, publicado em 1926, alguns meses após o Congresso Regionalista:

Recife era uma velha cidade cheia de ruas estreitas e casas sem conforto; as obras do porto conseguiram renovar rapidamente uma pequena parte, que é hoje um contraste com os "mucambos" que povoam os mangues, e, o que talvez seja peior, a casaria velha e condensada que cobre o bairro de São José, e não é rara nos bairros de Recife, Santo Antonio, Bôa-Vista e Santo Amaro. ${ }^{59}$

Não julgou conveniente expressar suas críticas às casas urbanas antigas, ao abordar a arquitetura no congresso, mas não alterou sua posição frente a elas. Na palestra, falou em conservar monumentos e igrejas, mas das casas urbanas ou rurais - limitou-se a postular, em novas e higiênicas construções, a recuperação de um certo "caracter" das antigas.

Amaury e Freyre não puderam escapar, portanto, de travar um difícil diálogo entre a higiene e tradição. Freyre nunca escondeu suas simpatias por Amaury, a quem incluiu na nova geração de médicos recifenses, "cujo prestigio, influencia e relevo de acção" justificou, por constituírem "a melhor energia moça da terra". Avaliou que benefícios "[...] hão de vir da acção do jovem hygienista [...] de notaveis possibilidades de influencia social, além das de ordem technica".60 
Em outra ocasião elogiou a ação o médico na chefia dos serviços de higiene de Pernambuco, pela campanha de propaganda e educação sanitária que comandava. ${ }^{61}$ Em 1924, aplaudiu Amaury pela "[...] idéa feliz de trazer do Rio, centenas de arvores hoje disseminadas pelo Recife". ${ }^{62}$ Indícios de amizade entre ambos são sugeridos em escritos de Freyre, antes e após a morte de Amaury, assim como ao tê-lo sentado a seu lado no jantar em que se despediu dos amigos no Restaurante Leite, em março de 1926, na véspera de viajar aos Estados Unidos para participar do Congresso Pan-Americano de Jornalismo. ${ }^{63}$

Contudo, por temperamento e por convicções, Freyre tinha motivos para discordar de Amaury em temas sensíveis ao médico. Conforme confessou, era tendência de seu espírito "[...] pôr logares-communs pelo avesso. Um logar-commum pelo avesso é quasi sempre perturbante verdade". ${ }^{64}$ No momento em que a higiene se convertera em um poderoso lugar-comum no Recife, era previsível que a questionasse, sobretudo quando podia apoiar-se em firmes convicções.

Assim, Freyre foi um crítico vigoroso e corajoso do higienismo que imperava no ambiente médico, técnico e intelectual recifense, durante a década de 1920. Nunca ocultou sua aversão pelo ímpeto com o qual Amaury abraçara a reforma sanitária e se lançara em uma profunda intervenção higienista na cidade e nos hábitos de seus moradores. Já em setembro de 1924, em resenha sobre o livro Cruzada Sanitária, de Amaury, Freyre reduziu esse ímpeto a uma espécie de devoção, que chamou de "messianismo hygienico" e "mysticismo sanitario", enquanto ao médico reservou o posto de "cruzado de Nossa Senhora da Saude", muito incômodo para alguém que se julgava um arauto da ciência:

E seu livro parece gritar: fóra da hygiene não há salvação! Ou: a salvação do Brasil está no seu saneamento! [...]. Messianismo hygienico, o do sr. Amaury de Medeiros, que aliás desdenha com um sorriso sceptico dos outros messianismos. Mysticismo sanitário, o seu.

E parece que o ideal patriotico do sr. Amaury de Medeiros seria um Brasil que parecesse com um reclame de Emulsão de Scott ou de Sabão Aristolino. No que divergimos profundamente. Eu de modo nenhum posso admitir a sobremacia dos valores sanitarios. Aos meus olhos o papel de solfa sempre valerá um pouco mais que o papel hygienico. E a ltalia, por mais verdes que sejam as dentuças dos milanezes e por mais miasmaticas que sejam as aguas de Veneza e por mais sujos que sejam os beccos de Napoles, será sempre um tanto mais culta que a Suissa ou a Finlandia. Fóra da hygiene bem que há salvação. ${ }^{65}$

Freyre achava necessário esclarecer não ser hostil à higiene, mas contrário à ênfase que essa e outras "tendencias pragmaticas" vinham recebendo no país:
61. Id. (1923b, p. 1).

62. Id. (1924f, p. 2).

63. Id. (1926a, p. 3).

64. Id. (1923c, p. 1).

65. Id. (1924e, p. 3). 
66. Id. (1924e, p. 3)

67. Id. (1924c, p. 3).

68. Dr Amaury de... (1923,

p. 1).

69. Freyre (1924e, p. 3).
Si ao evangelho do sr. Amaury de Medeiros - isto é, ao seu simplismo - opponho lealmente restricções, não é porque o desdenhe: é porque as tendencias pragmaticas vão tomando relevo e volume taes no Brasil que os interesses da pura cultura e da superior delectatio precisam de uma voz ou outra capaz de desafinar-se do côro para os exaltar. ${ }^{66}$

Em torno das janelas, Freyre e Amaury não se entendiam em definitivo: enquanto o sociólogo saudava nostálgico "as velhas janellas recifenses [...] a deitar para nós seus ultimos olhares", ${ }^{67}$ o médico as queria reformadas, desertas e reduzidas a dispositivos sanitários.

Em jantar em sua homenageavam, em outubro de 1923, Amaury fez um discurso para amigos, no qual procurou expressar sua indiferença às críticas que sua gestão do DSA vinha recebendo, contrapondo o presente ao futuro, que dizia confiar the daria razão. Empolgado com o argumento, chegou a assegurar: "Só o futuro me interessa, só elle me preoccupa e seduz, o passado já o disse uma vez, é uma contingencia necessaria, o proprio presente uma passagem obrigatória". 68 O discurso, publicado no livro Cruzada Sanitária, não passou despercebido por Freyre. Na resenha sobre o livro, disposto a rechaçar o ímpeto reformista do autor em suas várias dimensões, não the perdoou pela ênfase no futuro e na construção do novo, com suas implicações na visão de passado:

Tão pouco poderei deixar sem reparo esta confissão do sr. Amaury de Medeiros: "Só o futuro me interessa, só elle me preoccupa e seduz, o passado... é uma contingencia necessaria, o proprio presente uma passagem obrigatoria". Má orientação. É como si um homem de trinta annos dissesse: só meus netos me interessam; meus paes são uma contingencia necessaria; mesmo minha mulher é uma simples passagem obrigatoria.

De novo nossa divergência é radical. Ninguem terá menos a superstição do passado do que eu. Ninguem terá mais vivo o horror ás formas consagradas. $\bigcirc$ horror á immobilidade do espirito e a repressão da vida sob a dura crosta de classicismo.

Mas ha uma grande delicia em furar o duro gelo da crosta, ao geito dos pescadores canadenses; e pescar no passado; e alimentar-se delle para melhor crear e produzir.

A cultura é como a fidalguia: não se improvisa [...]. Para haver cultura de linhagem é preciso que haja vivo contacto com o passado; que o passado forneça as normas para o actual.

Eu não comprehendo a vida bem orientada fóra do fecundante contacto com o passado. Nem vida nem architectura nem politica nem cousa nenhuma. $O$ passado é, pois, muito mais que contingencia necessaria: energia creadora. Só aos que se deixam abafar nas suas dobras hieraticas elle esteriliza e immobiliza.

Perdóe-me o sr. Amaury de Medeiros mais esta restricção; eu, porém, não the saberia perdoar ao claro espirito uma tão injusta attitude. É preciso que nos convençamos de que o passado é vida para ser continuada, e não destruída ou mutilada nem tão pouco servilmente copiada. ${ }^{69}$ 
No início da noite de dois de setembro de 1924, dia em que o Diario de Pernambuco publicou essa resenha, o Centro Regionalista se reuniu e é possível pensar no artigo de Freyre entre os "assumptos de vivo interesse" que a imprensa anunciou seriam tratados na reunião. ${ }^{70}$

Freyre reconheceu em Amaury entusiasmo, inteligência, bom gosto, talento e capacidade de ação, como sugere resenha, que publicou dois anos depois, sobre o novo livro do médico, Saúde e Assistência:

No sr. Amaury de Medeiros se agita um dos mais quentes enthusiasmos da nova geração brasileira de medicos; e a serviço deste enthusiasmo, cheio de volupia das realizações immediatas e das victorias festivas, está uma das intelligencias mais americanas que tenho conhecido no Brasil; está um gôsto a que não falta elegancia; está todo um conjuncto brilhante de recursos de talento e de acção.71

Não há porque duvidar, contudo, que Freyre preferisse ver o médico menos animado e ativo em suas iniciativas no campo da higiene.

É bem possível que a interlocução com Freyre tenha contribuído para colocar algum freio nas tendências reformadoras de Amaury, para o que também pode ter agido sua sensibilidade à arte. Esta, aliás, reconhecida-com surpresa-por Freyre, que se admirava por não ter sido aniquilada pelo higienismo exaltado do médico:

[...] não perdeu o jovem higienista, no contacto com os reagentes e os microscopios, esse sentido do bello que na Edade Media tanto se exaltou. São Thomaz dizia que sem o delectatio era impossível viver; e por isso queria que o delectatio espiritual se sobrepuzesse ao carnal. $\mathrm{O}$ sr. Amaury de Medeiros quase repete o Santo, perguntado no mais lindo e vibratil dos seus discursos, de que valeria, afinal, a vida, "sem essa inutilidade indispensavel que é a arte?"

E ahi se revela o grande voluptuoso das cousas bellas que realmente é. ${ }^{72}$

De fato, após acompanhar por três anos a animada cruzada sanitária liderada por Amaury, Freyre parecia ter-se convencido de que apenas o "gosto" conteria o "preconceito hygienico" que estaria se apoderando dos médicos. ${ }^{73}$

Entre divergências no campo da higiene da habitação e afinidades em face à arte e à arquitetura, estabeleceu-se um rico diálogo entre ambos. A casa era o delicado ponto de contato entre convergências e arestas. $\bigcirc$ regionalismo precisou escolher, entre os dois, um intérprete para o tema no seu congresso, posição que recaiu sobre Amaury, talvez favorecido por estar atuando como "arquiteto". Assim, no evento, cautelosamente, Freyre e Amaury trataram de temas distintos e não precisaram expor
70. Centro Regionalista do... (1924a, p. 3).

71. Freyre (1926d, p. 3).

72. Id. (1924e, p. 3).

73. Id. (1926f, p. 3). 
74. Medeiros (1926c, p. 3).

75. Ibid. (1926c, p. 3). os contrastes entre suas posições frente à arquitetura e à cidade do passado: o sociólogo encarregou-se do tema da culinária e o médico chamou a si o da arquitetura.

Na conferência intitulada "Estylo Colonial de Architectura do Ponto de Vista da Hygiene Moderna", pronunciada no Congresso, Amaury defendeu que o "estylo colonial" - ou a "architectura tradicional" "pode adaptar-se a todas as exigências das modernas leis sanitárias" e "receber sem prejuizos todos os aperfeiçoamentos da civilização". ${ }^{74}$ Não deixou claro, contudo, se acreditava que tal possibilidade estaria aberta à habitação herdada do passado. Por meio de suas ações no DSA, de leis propostas e artigos escritos, é lícito supor que considerava que a adequação das casas antigas às "exigências das modernas leis sanitárias" estaria condicionada, pelo menos, a uma reforma radical das instalações sanitárias e à abolição de alcovas (por meio de poços de ventilação, por exemplo). Em seu discurso, no jantar de encerramento do evento, Amaury defendeu ser possível adaptar aspectos da cidade do passado à higiene:

Trabalhar pela conservação da nossa paysagem, conservando as velhas arvores caracteristicas da região e plantando novas; manter tanto quanto possivel as nossas casas de beiraes a mostra, pontilhadas de azulejos, destes bellos azulejos que nos legaram os nossos avós; amar as deliciosas pinhas de louça do Porto, os jarrões, os carrucheis que o tempo não poude consumir e dão vida as velhas fachadas; manter nos nossos interiores os moveis commodos e solidos de jacarandá; construir nos nossos interiores os claustros frescos e mansos tão convenientes ao clima, feitos para a meditação dos conventos, mais muito doces para repouso do ambiente familiar; conservar os nossos habitos hospitaleiros onde os quitutes e os doces são talvez a forma mais ingenua mais sincera e mais carinhosa de conquistar e prender; tudo isto é contribuir para dar uma physionomia e um caracter a Patria comum, a forma mais util, mais elegante e mais positiva de fazer um necessario nacionalismo, unindo a todos pelo gosto, pelos habitos e pelas tradições.

Vimos no correr deste Congresso que a conservação dos costumes tradicionaes não tem nenhuma incompatibilidade com os progressos da architectura, com a hygiene moderna, com nenhum dos progressos da civilisação; vimos que a casa colonial conservando seu caracter, póde receber todo o conforto actual; vimos que para resolver problemas de transito não é preciso arrazar a picareta monumentos historicos; que o bom urbanista sabe como harmonisar uma velha igreja com uma nova rua; vimos que para cuidar da conservação do nosso patrimonio artistico tradicional não se precisa arruinar o paiz... ${ }^{75}$

Acima, a casa que julga compatível com a higiene é a nova "casa colonial", não a velha moradia herdada do passado. Quanto às velhas igrejas, admite que poderiam conviver com novas ruas, saneamento e tráfego. No congresso, não reafirmou, nem negou o que havia dito e escrito sobre o tema da 
moradia. Não atacou as "casas sem janelas", as alcovas que tanto odiava, os charcos e lagoas tão característicos da paisagem regional do litoral nordestino e o tradicional pinhão ostentado em lugar de destaque nos jardins. Sobre eles, calou-se. Da paisagem existente, voltou-se para as velhas árvores e omitiu os charcos. Defendeu as velhas igrejas, mas não a manutenção - caso o tráfego "exija" - da malha urbana e dos pátios no entorno delas. Entre suas referências para o interior das casas estavam os claustros "frescos e mansos" de mosteiros. Sugeriu uma renovação da habitação, na qual as novas moradias buscariam nos velhos claustros referências de ordenação do espaço e nas antigas casas o "caracter", motivos ornamentais, mobiliário e telhado prolongado em beirais.

Em novembro de 1926, em resenha sobre o livro Saúde e Assistência, Gilberto Freyre lembrou as críticas que havia dirigido ao "messianismo hygienico" que identificava em Amaury, que atingem, ainda, os literatos locais que aderiram a um "Concurso Littero-Sanitario" promovido pelo médico, cujo júri contou com dois sócios do Centro Regionalista: Annibal Fernandes e, ninguém menos que o presidente, Odilon Nestor:

Eu me sinto um tanto a vontade para dizer todo o bem que penso do sr. Amaury de Medeiros. Nossas divergencias de pontos de vistas sempre foram maiores que nossas coincidencias; e eu as manifestei num tempo em que não era chic fazel-o. Tempos em que a litteraturasinha da terra andava tão engraçadamente a fazer reclame de "lavae as mãos antes de comer", "cuidado com as moscas", "escarrar no chão é má acção". Isto em contos, ensaios, versos. Um regalo.76

Nessa resenha, contudo, Freyre parece admitir ter refreado seus ímpetos tradicionalistas. Lembra-se, como de algo deixado para trás, dos momentos iniciais de seu retorno ao Recife, quando chegara a relacionar "a immundicie e o gênio artístico" em alguns povos e "a hygiene e a esterilidade de espirito" em outros. Enfim, quase associara higiene com mediocridade. Já em 1924, mostrava-se mais moderado ao deixar de incluir os sobrados dos bairros centrais entre as construções a preservar, ao se defender de um engenheiro que o acusou de ser favorável a um Recife "[...] sujo, fedendo a toda especie de immundicie sem os beneficios da esthetica moderna e da hygiene [... $]^{\prime \prime}$ :

Sou de facto pela conservação de muita cousa velha do Recife: das velhas egrejas, por exemplo. E dalguns palacetes como o da Soledade e outros que se avistam de qualquer bond de Dois Irmãos ou de Magdalena. Devo confessar que prefiro o "sujo de velhice" á tinta fresca. Mas reconheço a necessidade de construir e reconstruir. E o que 
77. Id. (1924b, p. 1).

78. Id. (1926d, p. 3). eu quero, sobretudo, é um Recife que se renove sem perder o caracter, numa economia intelligente e honesta dos valores proprios e dos motivos tradiccionaes.

Z zig-zag dalgumas ruas antigas me parece encantador e considero verdadeira tolice querer reduzir a cidade a tabuleiros de xadrez. O zig-zag das ruas cousa nenhuma tem de anti-hygienico [...].

Quanto a edificações novas sabemos que ellas podem ser todas dentro do caracter da cidade. Que o digam as residencias do Sr. Othon de Mello e do Sr. Arthur Lício.77

Neste ínterim, Amaury, por sua vez, conteve um pouco sua sanha higienista. Esse duplo movimento dos dois contendores permitiu a Freyre terminar a resenha de forma surpreendente, com um rasgado - para usar um termo que apreciava - elogio ao médico:

[...] recifense nenhum, em dia com as actividades de seu burgo, negará ao sr. Amaury de Medeiros nestes tres ou quatro annos de acção enthusiastica, beneficios á vida da cidade; accrescimos á sua beleza e até, nos últimos dois anos, inteligente esforço de defesa da sua physionomia tradicional. ${ }^{78}$

Essa defesa da "physionomia tradicional" pode ser pensada em termos da promoção do estilo neocolonial e da abstenção de demolições de ordem sanitarista na cidade antiga que, sem dúvidas, implicou uma reavaliação das concepções de Amaury acerca da relação entre a higiene e os lugares herdados do passado. Impôs considerar a complexidade cultural e as heranças históricas e ambientais da cidade, a par de seus problemas sanitários. Isto the exigiu reavaliar alguns consensos sanitaristas e ponderar alguns efeitos colaterais da dose de higiene que estava empenhado em ministrar na cidade.

Este pode ter sido o elogio de maior alcance recebido por Amaury. Seria muito esperar que Freyre reconhecesse de forma clara a melhoria das condições de higiene da cidade e das casas, que fica, assim, computada nos "benefícios". O elogio veio quando Amaury já havia se afastado da direção do DSA e, assim, presta-se a uma avaliação de sua trajetória no órgão. Atesta que, em meio à sua febril atividade de sanitarista, teve tempo para fazer uma importante autocrítica, revendo alguns dos métodos de ação da higiene para conciliá-los com a defesa da cidade herdada do passado. 
Entretanto, nem tudo estava "resolvido" entre Amaury e Freyre. Em outro tema - o mocambo - não parece ter havido possibilidade de conciliação entre ambos. Em 1925, Freyre já havia formulado e divulgado corajosas teorias acerca das qualidades estéticas e ambientais que atribuía ao mocambo, nas quais insistia na injustiça e imprecisão das acusações de ser uma moradia anti-higiênica e antiestética. No Centro Regionalista, apinhado de médicos, esse deve ter sido um tema dos mais palpitantes. Naquele momento de grande prestígio da higiene, não só com sanitaristas Freyre precisou bater-se. Já em 1921, por exemplo, uma campanha contra o mocambo fora empreendida por Annibal Fernandes, na sua coluna no Diario de Pernambuco.

A partir de 1923, no Recife, Amaury assumiu o protagonismo da campanha pela reforma da moradia. No caso dos pobres, estabeleceu uma relação ainda mais direta entre condições de moradia e enfermidades. Entendia que no Recife tal relação se agravava, por dois motivos: a cidade, situada no delta de dois rios, era baixa; e o pobre se empenhava - na sua concepção, teimava - em ter uma casa própria:

Na população pobre, lá, ha uma inversão economica: todo o pobre possue sua casa; o rico geralmente não; a classe media mora em immoveis alugados. $\bigcirc$ ideal daquella gente humilde é ter a sua casinha, a que denomina "mucambo".79

Essa casa foi descrita por Amaury em termos nada lisonjeiros (figura 16). Assinalou nela um vasto elenco de precariedades: materiais de construção, localização, distribuição dos espaços, dimensões dos ambientes e ausência de janelas nos quartos:

Esta é uma mistura heterogenea de varios materiaes, que se podem prestar ou já se prestaram á construcção, postos em equilibrio quasi instavel, em baixo dos quaes se abriga o desgraçado e se diz satisfeito porque possue o seu "cantinho".

Tal habitação, que existe em numero regular em Recife, é tudo quanto ha de negação no ponto de vista hygienico. Está collocada nas zonas mais baixas da cidade, por vezes em ilhas. Não tem esgotos nem agua corrente. Quando chove, o que acontece frequentemente, a agua entra na casa. 
80. Ibid. (1926a, p 139).

81. Ibid, (1926a, p. 139).
Figura 16 - Amaury - cabeça inclinada e braços cruzados diante de um mocambo, em companhia de outros dirigentes do serviço estadual de saúde. Medeiros, $1926 a$, p. 135.
A disposição da casa é a seguinte: uma sala na frente (sala de visitas!); dois pequenos quartos, sem janela, dando para um corredor e uma "sala de jantar", um fogão de barro no quintal.

Toda a casa é dentro de uma area que não excede de 3 metros por 5.80

Para ilustrar a relação que estabelecia entre este tipo de moradia e a proliferação de doenças, recorreu ao relato de um caso extremo:

De uma feita, o guarda de um certo districto annunciou que em um mucambo que visitára, em serviço de policia sanitaria, encontrára toda a familia doente. Fui pessoalmente verificar o caso. Era uma familia de 6 pessoas, mãe viuva e 5 filhos, o mais velho, um rapaz, responsavel pela casa, agonisava de uma infecção que verificamos ser paratyphica. A habitação era muito estreita, escura e suja, exatamente com as disposições descriptas e todos que nella residiam estavam contaminados pela mesma doença.

Se se tratasse de uma casa em outras condições hygienicas, com maior espaço, mais luz e agua corrente, exgoto, o mal não teria assim disseminado de uma vez. Os exames de laboratorio foram positivos: tratava-se de febre paratyphica, e o germen era identico em todos os doentes.

Essas casas são, pois, tudo quanto há de mais insalubre. Por felicidade, ellas são, em geral, situadas em logares baixos, como vimos, e cercadas de agua salgada que se renova todos os dias: são verdadeiras habitações lacustres. ${ }^{81}$

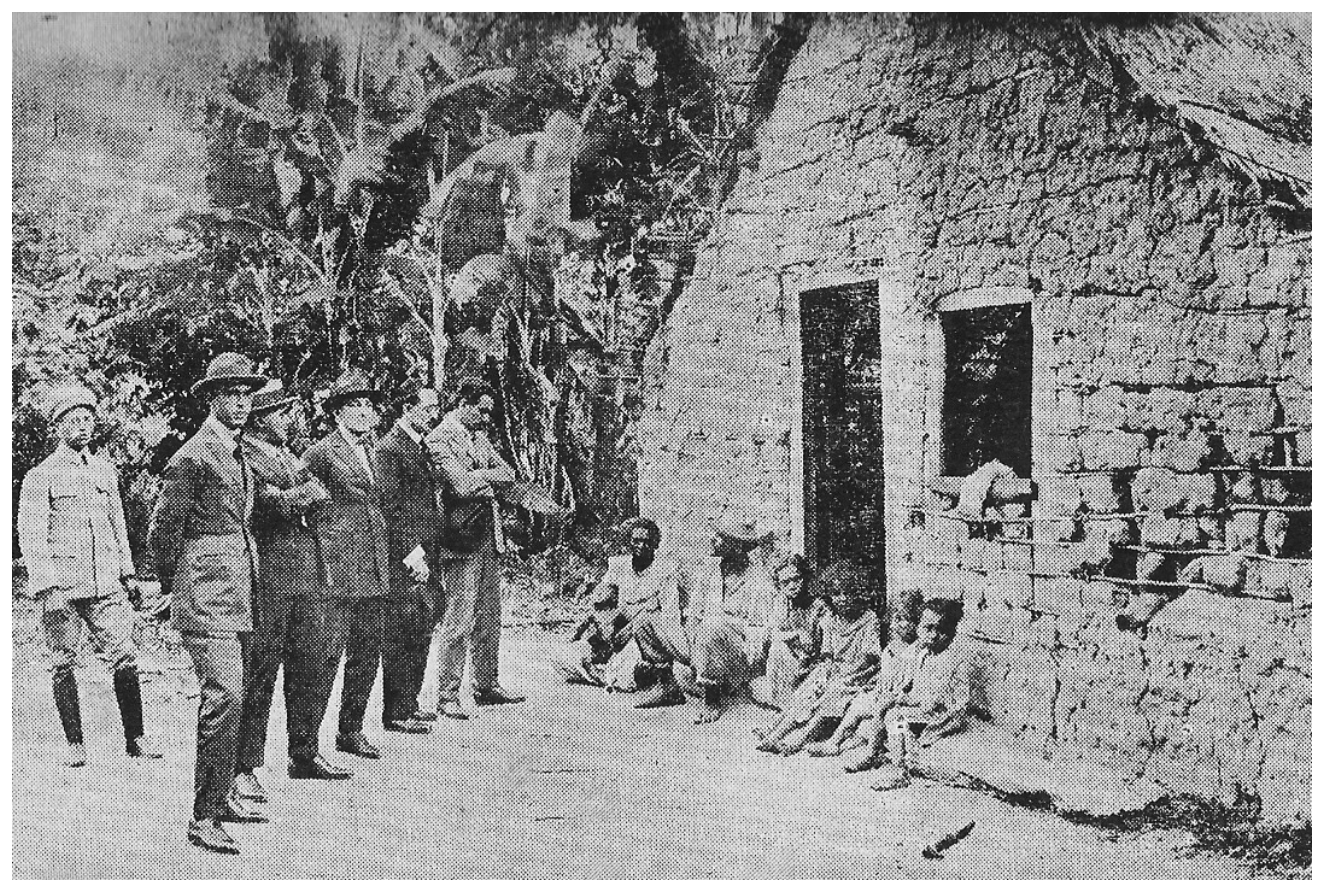


No seu discurso, na cerimônia de inauguração da Vila Operária Paz e Trabalho, em maio de 1925, Amaury declarou que aos mocambos do Recife preferia as cabanas de Dakar, "[...] mais primitivas, mais selvagens, porem, mais limpas, menos humidas e mais caracteristicamente indígenas". ${ }^{82} \mathrm{Na}$ fala, criticou não apenas os mocambos do Recife - com "ar de farrapo e de mizeria" e "formados de restos e detrictos de civilisação" -, como os que neles identificavam qualidades:

Berço tradicional de todas as liberdades e de muita pieguice mal entendida e nociva, a demagogia aqui se firmou para luctar contra o bem geral e por isso o Recife tem, mais do que qualquer outra cidade, criado, alimentado e mantido os seus maiores inimigos. ${ }^{83}$

Tudo indica que a "pieguice mal entendida" atribuída aos que viam qualidades arquitetônicas nos mocambos se referisse a Gilberto Freyre, seu mais notório defensor. No mesmo mês, em matéria no Diario de Pernambuco, o jornalista Mario Mello manifestou suas discordâncias do sociólogo quanto à conservação dos mocambos, argumentando serem "[...] muito pittorescos, essencialmente poeticos mas anti-hygienicos segundo nos ensina Amaury de Medeiros" ${ }^{84}$

As formulações de Freyre sobre o mocambo não tardariam, contudo, a encontrar um aval vindo da medicina, na tese apresentada em 1929 pelo médico pernambucano Aluísio Bezerra Coutinho. Nela, o autor defendia ser o mocambo do sertanejo do Nordeste - com paredes de taipa e cobertura de palha - um exemplo de moradia adequada ao clima e propícia ao bem-estar do morador. ${ }^{85}$

Anos depois, em 1937, Freyre publicou o livro Mucambos do Nordeste. Algumas Notas Sobre o Typo de Casa Popular mais Primitivo do Nordeste do Brasil, no qual discutiu a gênese, os tipos, os materiais e métodos construtivos aplicados nestas moradias, assim como as qualidades ecológicas, estéticas e de higiene que nelas identificava. Nas diferentes técnicas construtivas utilizadas em mocambos, viu a preponderância ora da cultura indígena, ora da africana, da qual a moradia herdou o nome. Do ponto de vista estético, assinalou "[...] um traço de honestidade artistica do mucambo, com a sua simplicidade de linhas, a sua economia de ornamentos, o seu apoio quase exclusivo sobre a qualidade do material $[\ldots]^{\prime \prime 86}$ :

Na sua pureza de habitação vegetal, com os cipós fazendo as vezes de pregos e as portas feitas da propria palha ou folhas dos tapumes e da cobertura, o mucambo do litoral do Nordeste, quando construido no secco e entre coqueiros, exprime aquelle primitivismo de cultura de modo attrahente [...]. O seu ar é o de casas inteiramente á vontade entre palmeiras e á beira do mar ou da agua doce. ${ }^{87}$
82. Inauguração da "Casa... (1925).

83. Ibid. (1925).

84. Mello (1925. p. 3).

85. Coutinho (1930).

86. Freyre (1937, p. 29).

87. Ibid. (1937, p. 20). 
88. Coutinho (1930), Apud: Freyre (1937, p. 28).

89. Freyre (1937, p. 30-31).

90. Id. (1979b, p. 81).

91. Id. (1979b, p. 82).
No que diz respeito às condições de higiene e conforto, Freyre citou Coutinho para sublinhar a adequada conduta do mocambo em face às condições mesológicas: "o isolamento thermico proporcionado pelo material de que é feita a coberta", a palha, às vezes empregada também nas paredes, portas e janelas; "a ventilação devida á abertura deixada no frontão", a propiciar condições de iluminação e ventilação melhores que "seria licito esperar se se fizessem através de janellas, mesmo que largas". ${ }^{88}$ Assinala "seus oitões livres; sua aeração facil; sua insolação magnifica", para argumentar que, comparada à do cortiço,

[...] a vida em mucambo pequeno seria mais favoravel á ordem, ao asseio, á moralidade sexual. Pelo menos á monogamia, mesmo transitoria. E evidentemente mais favoravel á arte da renda, á do cesto, á do chapéu de palha, á da esteira e outras artes caseiras do Nordeste, nas suas formas mais modestas e simples que sempre acham jeito de florescer nos mucambos, principalmente nos das areas ruraes ou das praias, adoçando ahi a vida da mulher pobre, tão mais esmagada pelo trabalho duro e de rotina nos cortiços urbanos. ${ }^{89}$

Em obra posterior - Oh de casa! Em torno da casa brasileira e de sua projeção sobre o tipo nacional de homem -, Freyre voltou ao tema. Situou o mocambo entre os exemplos nordestinos de casas adequadas aos trópicos que, no seu entender, incluíam também a casa-grande de engenho, o sobrado urbano e a casa-forte de pedra e cal, nas quais via influências portuguesas enriquecidas pela experiência asiática e contato com os mouros. Insistia que o mocambo, com influência predominantemente africana e indígena, constituía uma herança cultural relevante e uma moradia com qualidades ecológicas que não podiam ser desprezadas. Entre seus méritos estéticos, chamava atenção para os traçados que, "[...] quando mais artísticos, se assemelham a uma arte da renda em que, com a palha, se conseguissem efeitos, além de funcionais, atraentes e até belos". 90 Admitia que nos mocambos construídos de palha, o material não tinha longa duração, mas insistia que não era, por natureza, anti-higiênico: "Ao contrário: favorece melhor que o tijolo a aeração e a insolação dos interiores das residências." Entendia que suas deficiências em termos de higiene podiam ser resolvidas com reforma do piso e introdução de instalações sanitárias. Contrapunha-se à eliminação de tais habitações, sustentando que, assim como alguns preferem dormir numa rede ameríndia "fresca, limpa, artística" a fazê-lo em uma cama europeia, outros podem preferir o mocambo à casa de tijolos por serem "[...] seus próprios arquitetos, dentro de tradições de cultura e formas de vivência de sua predileção". 91

Cabe assinalar que o Manifesto Regionalista - lido em 1951 - registra uma inflexão curiosa nas posições de Freyre em face à higiene: articula o elogio do 
mocambo a uma crítica higienista ao modelo de casa urbana herdado do passado.

92. Id. (1996, p. 53).

93. Id. (1996, p. 54).

94. Id. (1996, p. 54).

[...] habitação superior a esses tristes sepulcros nem sempre bem caiados que são, entre nós, tantas das casas de pedra e cal, sem oitões livres e iluminadas apenas por tristonhas claraboias que apenas disfarçam a falta de luz e a pobreza de ar, dentro das quais vive vida breve ou morre aos poucos - quando não às pressas, arrastada pela tísica galopante - a maior parte da gente média da região, nas cidades e até nos povoados. ${ }^{94}$

Assim, Freyre combateu a higiene quando a identificou como risco à cidade antiga, para reabilitá-la, anos depois, no âmbito do elogio ao mocambo. Em meados da década de 1920, fazendo ressalvas ao higienismo, celebrando as ruas estreitas e elogiando o mocambo, Freyre não podia escapar de animar as reuniões na casa de Odilon Nestor, batendo-se com Amaury e outros "apóstolos" da higiene.

\section{O FIDALGO E O HOMEM EM CAMPANHA}

Na manhã do dia três de dezembro de 1928, Amaury morreu em um famoso acidente aéreo, em meio ao grande rebuliço que sacudiu o Rio de Janeiro no retorno de Santos Dumont ao Brasil. Quando se preparava para saudar Dumont, lançando mensagens e flores sobre o navio que o trazia à cidade, um avião transportando, entre outros, Amaury e um grupo de professores da politécnica, mergulhou nas águas da baía, nas quais morreram todos seus ocupantes.

Freyre estava em um velho engenho de parentes em Alagoas, onde passava temporadas de verão, quando recebeu a notícia. De lá, sob o pseudônimo Jorge Rialto, enviou para A Provincia um artigo no qual refletiu sobre o médico e as circunstâncias do final de sua vida: 
95. Rialto (1928b, p. 3).

96. Ibid. (1928b, p. 3).

97. Id. (1928a, p. 3).
Havia em Amaury de Medeiros um espirito publico, ou seja, um gosto de iniciativas de interesse publico, sempre prompto a associar-se a movimentos generosos [...].

Amaury de Medeiros era um idealista a quem não faltavam a coragem e o gosto da acção. Só estava bem quando em campanha, quando em lucta por um ldeal que ao meu vêr ele via e sentia sempre como os symbolistas, com a inicial grande, mysticamente maiuscula, irresistível. ${ }^{95}$

Avaliou que aquela morte não combinava com o médico:

Nunca imaginei que Amaury de Medeiros viesse a morrer tão cedo. Elle era desses homens moços junto de quem a gente facilmente antecipa uma vida largamente victoriosa, sempre de acção, sempre de sucesso, terminando numa forte e serena velhice. Ninguem, junto de Amaury de Medeiros, podia pensar numa morte estupida aos trinta e quatro ou trinta e cinco annos, das que neste mesmo Brasil, hoje tão dynamico, estiveram muito em moda no tempo de Alvares de Azevedo. A um temperamento como o de Amaury de Medeiros, ancioso de horizontes largos, voluptuoso da acção e do esforço, nunca poderia ter seduzido aquella moda romantica de morrer moço - embora dentro delle houvesse um grande romantico, um sonhador capaz de fazer versos, e que effectivamente os fez, algumas vezes, nos ocios da vida agitadissima de hygienista desdobrado em administrador que aqui levou durante quatro anos intensos. ${ }^{96}$

As situações contrastantes nas quais foram alcançados por aquele momento dizem muito dos dois: o sociólogo na madorra de um velho engenho, em busca do passado de sua família opulenta; o médico celebrando o presente e a técnica em uma instável máquina moderna nos céus de uma metrópole em ebulição festiva. Alguns dias depois, Freyre voltou ao tema, agora lançando o olhar ao futuro, para avaliar que, com a morte trágica de Amaury, Pernambuco teria perdido "[...] uma das suas mais brilhantes esperanças". 97

Com seus interesses diversificados, espírito prático e ampla influência no governo, Amaury deu apoio institucional e organizacional aos dois eventos promovidos pelo Centro Regionalista e promoveu, em obras do estado, o estilo neocolonial de arquitetura. Sem ter formação em arquitetura ou engenharia, ousou transpor para projetos temas tratados pelos regionalistas. Aplicou o neocolonial em obras do DSA/ SPSR e no grupo escolar cujo prédio projetou, compondo um conjunto de construções de grande unidade formal, ancorada em formas simples, na busca de referências na arquitetura local do passado e na implantação em meio a jardins. É possível que tenha atuado para convencer seu tio prefeito, Antônio de Góes, a adotar o estilo no Mercado da Madalena e influenciado as feições do prédio da Faculdade de Medicina, construído sob o comando do médico Octavio de Freitas. Não deve ter encontrado dificuldades para influenciar as discussões iniciais em torno do projeto da Maternidade 
do Derby, construída pela Cruz Vermelha Pernambucana e presidida por sua sogra, Virgínia Loreto. Nesses dois últimos casos, os prédios, embora erguidos por instituições autônomas, receberam subsídios diversos do governo estadual e integraram a mais expressiva realização do governo Sergio Loreto no campo do urbanismo: o Derby.

O apreço pela arquitetura do passado encontrou, contudo, outras expressões no governo de Sergio Loreto. Uma delas foi o reparo de alguns prédios em estilo neoclássico, construídos no século XIX, como as antigas instalações do Asilo de Alienados e o prédio, antes ocupado pela Diretoria de Higiene, reformado e restaurado para abrigar o Grupo Escolar João Barbalho.

Outro indício de respeito, de alcance maior, desse governo pela arquitetura e pelo ambiente urbano do passado foi a não destruição de bairros antigos da cidade através de obras de reforma urbana. $\bigcirc$ governo de Sergio Loreto realizou grandes obras de urbanismo no Recife, sem fazer qualquer destruição massiva de prédios e casas antigas. As obras realizadas - praças, ruas, avenidas, escolas, hospitais e vila operária - dirigiram-se para terrenos não construídos, sobretudo campinas, charcos e gamboas. Nem mesmo toda a crítica de ordem higienista feita por Amaury às casas antigas - às tais casas "sem janelas" - autorizou-o a pleitear qualquer investida contra a cidade histórica. Uma exceção, ao que parece única, foi a demolição do antigo quartel da Força Pública para a construção do Palácio da Justiça, que pode ser debitada ao governador-juiz desejoso de situar a sede do judiciário em local de indiscutível prestígio. No mais, Sergio Loreto e Antônio de Góes reformaram o Recife sem destruir a arquitetura e os lugares do passado. Com isso, estabeleceram grandes contrastes com governos posteriores e anteriores, alguns dos quais passaram despercebidos sem legar à cidade qualquer obra notável, enquanto outros nela deixaram sua marca à custa de um rastro de inclemente destruição de suas partes mais antigas. Puseram abaixo casas, arcos e igrejas, destruíram pátios e praças para abrir avenidas como a Rio Branco no início do século XX, a Guararapes durante o Estado Novo e a Dantas Barreto entre as décadas de 1940 e 1970, a última com agravante de desconectar a malha urbana e destruir lugares antigos sem uma justificativa funcional aceitável. Sergio Loreto e Antônio de Góes contornaram ambas as posturas: realizaram obras que deixaram uma marca definitiva na cidade, sem destruir. Apreciar o alcance dessa postura exige superar a atitude usual de considerar o governo pelas "realizações". As não "realizações" podem tanto ser indício de inércia, quanto de capacidade de discernir prioridades, de reconhecimento dos valores da cidade existente e de respeito por sua história e cultura. Assim sendo, o governo Loreto no campo do urbanismo foi notável tanto pelo que fez quanto pelo que deixou de fazer.

O significado da atitude dessa gestão em relação à cidade antiga também pode ser avaliado à luz do governo seguinte, de Estácio Coimbra 
98. Freyre (1968, p. 75).

99. Id. (1924a, p. 3).
(1926-1930). Às presenças de Gilberto Freyre e Annibal Fernandes em cargos de direção no governo, é possível associar algumas iniciativas importantes no campo da cultura, como a criação do Museu Histórico e de Arte Antiga (depois Museu do Estado de Pernambucol e da Inspetoria Estadual dos Monumentos Nacionais para defesa do patrimônio histórico e artístico, a publicação de obras inéditas de Pereira da Costa e de Alfredo de Carvalho, a melhoria das instalações da Biblioteca Pública e do Ginásio Pernambucano e a reforma da educação. Esse governo deu continuidade à ampliação dos serviços de água e saneamento, fez uma modesta ampliação do aparato do DSA com a criação da Inspetoria de Higiene Social e concluiu as obras do Palácio da Justiça.

Mesmo tendo criado uma Inspetoria Estadual dos Monumentos Nacionais, o governo Estácio Coimbra (1926-1930) foi capaz de cometer a gafe de aceitar as recomendações do urbanista francês Alfred Agache de escolha do local do Convento dos Jesuítas para a localização de um Grande Hotel. O mais surpreendente é que - como não teve o pudor de deixar de se denunciar - foi o próprio Gilberto Freyre, o tal enfant terrible que sugeriu o local a Agache. Décadas depois, vaidoso pela iniciativa - sabe-se lá porque - Freyre registraria no seu Guia Prático, Histórico e Sentimental da Cidade do Recife:

Quanto aqui estêve, ainda no tempo da República Velha, urbanista Alfred Agache, a convite do então governador Estácio Coimbra, tomou por guia um daqueles recifenses; e com êsse guia, então jovem - tanto que o francês o chamava de enfant terrible - procurou o Mestre Agache, com todo o rigor da sua ciência, o lugar ideal para um hotel recifense cuja construção o govêrno do Estado estava empenhado em estimular. O lugar escolhido, por sugestão do guia, aceita pelo mestre francês de urbanismo, foi aquêle onde hoje se ergue um hotel na verdade idealmente situado: o chamado Grande Hotel do Recife. $\bigcirc$ que nesse hotel não é ideal é sua arquitetura incaracterística. ${ }^{98}$

No texto acima, Freyre "esqueceu-se" de indicar que o lugar "idealmente situado" se encontrava ocupado pelo prédio que abrigara o antigo Convento dos Jesuítas e depois a sede do governo do estado - inclusive o instalado pela Confederação do Equador (figura 17). Tudo indica que esperava ver surgir no local do antigo convento uma expressiva construção neocolonial. É o que parecem sugerir as recomendações que havia formulado em 1924 - ao ser anunciada a intenção de Antônio de Góes de dotar a cidade de um hotel de luxo - que incluíam o edifício não ser "violentamente anti-esthetico" e sua arquitetura não contrariar "de todo nossas condições de cidade tropical, batida de sol"99. Inaugurado em 1938, o hotel exigiv a demolição de parte do convento e, erguido em meio aos ímpetos renovadores do governo Lima Cavalcanti, adotou o estilo art déco (figura 18). 


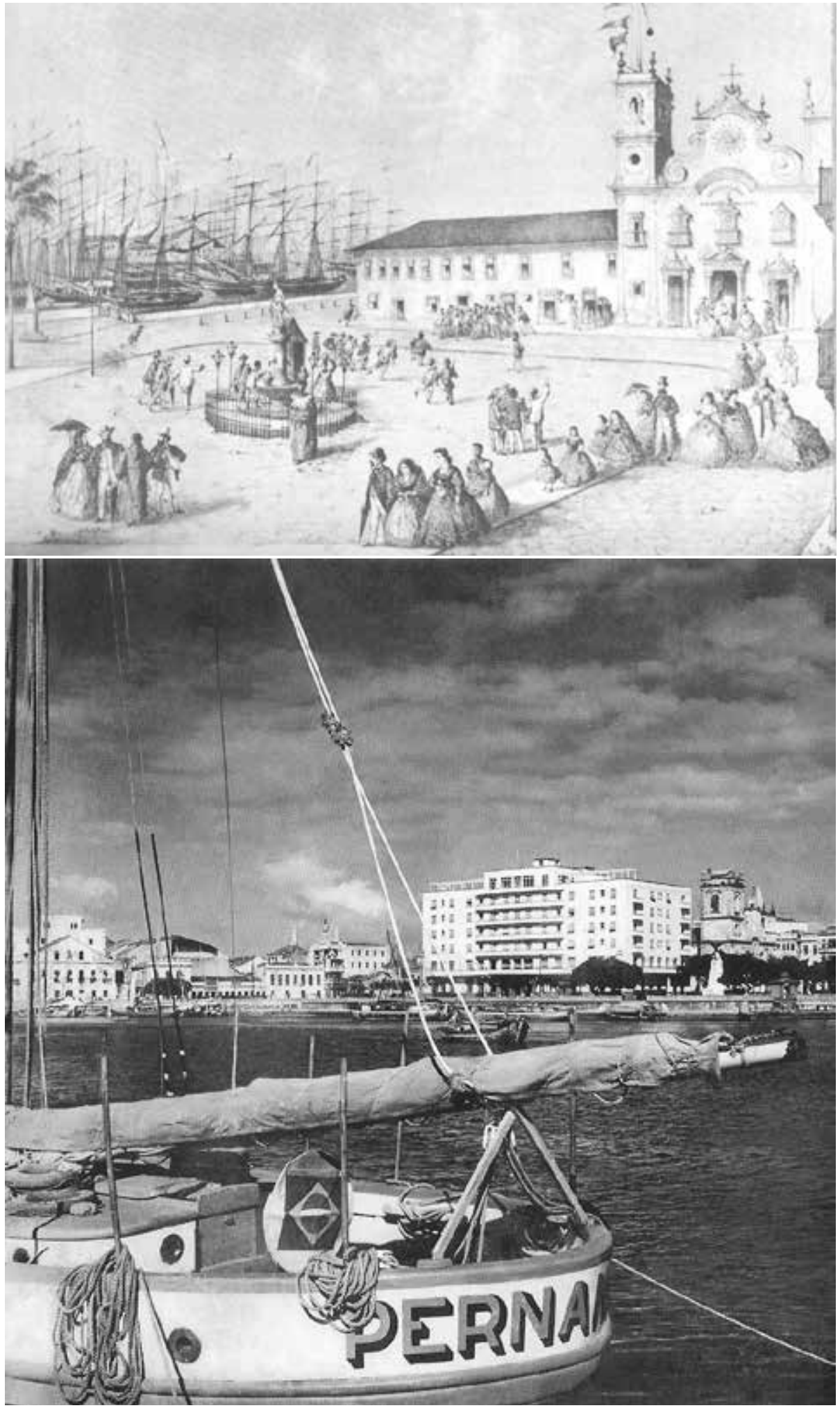

Figura 17 - A igreja e o antigo Convento dos Jesuítas, no século XIX. Fonseca, 1986, p. 30.
Figura 18 - $\bigcirc$ Grande Hotel, na década de 1940, ocupando o local do antigo Convento dos Jesuítas, a partir de surpreendente e desconcertante sugestão de Gillberto Freyre. Acervo do Museu da Cidade do Recife. 
No final da década de 1920, a provável pretensão de Freyre de destruir uma construção antiga para substituíta por outra, de viés neocolonial, não era original. Uma reforma de viés neocolonial já havia sido adotada na antiga Casa do Trem, no Rio de Janeiro, e viria a desfigurar o Convento de São Francisco, em São Paulo. No Recife, uma atitude dessa natureza ocorreu no governo de Estácio Coimbra, com a reforma de viés neocolonial do prédio da antiga Cadeia Pública para abrigar a Biblioteca Pública do Estado (figura 19). O prédio da cadeia fora construído por volta de 1730 e nele Frei Caneca esteve detido antes de ser executado, após a Confederação do Equador. A posição ocupada por Freyre no governo de Coimbra permite associá-lo à iniciativa de descaracterização do prédio. No governo anterior, com todo seu "messianismo higiênico" e apego ao neocolonial, Amaury conseguiu não incorrer em iniciativas dessa ordem.

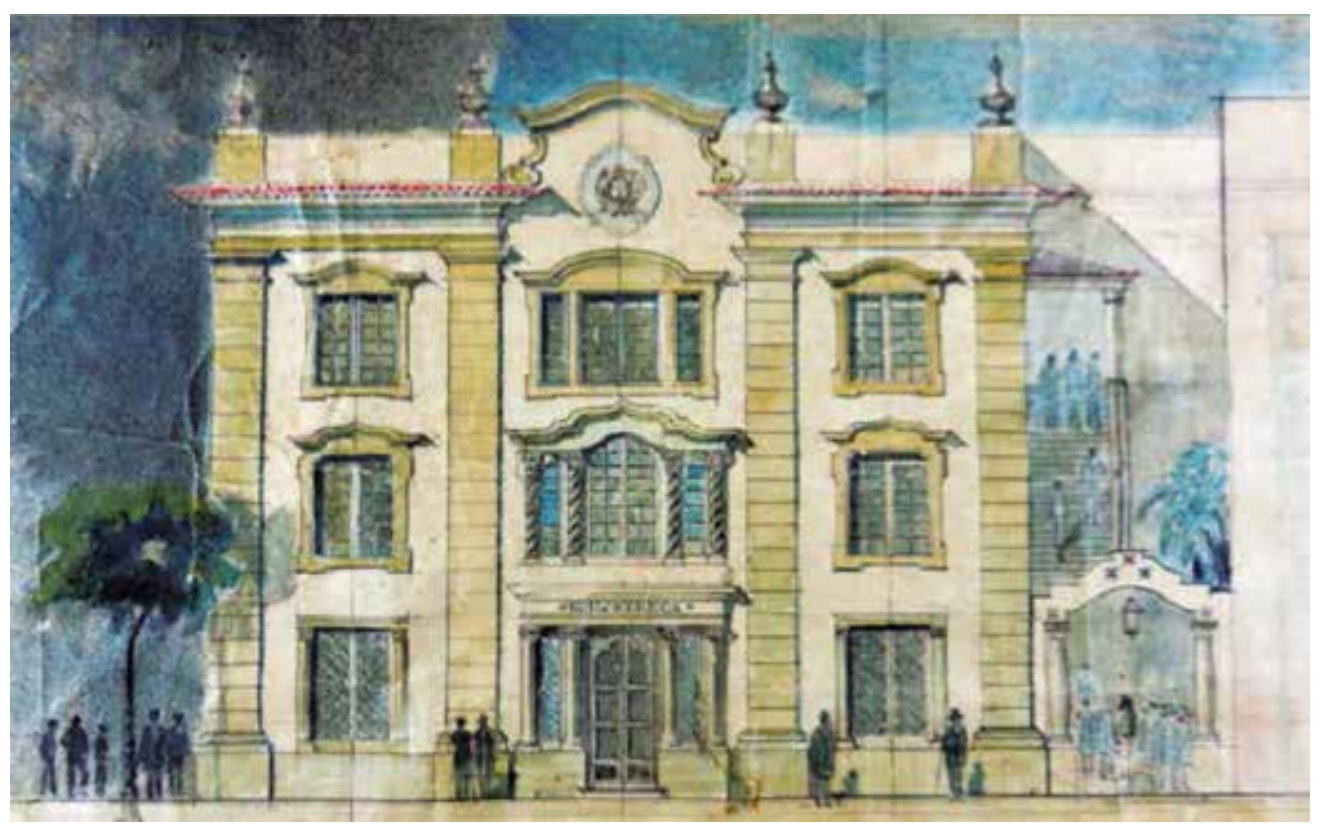

Figura 19 - Projeto de reforma do prédio da Cadeia Pública para abrigar a Biblioteca Pública, executada no governo Estácio Coimbra. Revista do APEJE. Recife, a. 1, n. 1, abr./mai./jul. 2016 (capa).

Embora tenha herdado parte da equipe - Ulysses Pernambucano, Samuel Hardman e Annibal Fernandes etc. - e do programa do governo anterior, o de Estácio Coimbra trouxe um ranço aristocrático, que contrastou não só com o governo Loreto, quanto com seu tempo e lugar. Certo "espírito de fidalguia" presente em suas iniciativas no campo da cultura se exprimiu de forma patente no empenho em 
"desaburguesar" as instalações do Palácio do Governo, pela compra de obras de pintores nacionais e estrangeiros e pela substituição da decoração com a qual, nas palavras de Gilberto Freyre, "[...] vinham se contentando sucessivos governadores, bons como cidadãos porém medíocres de gosto e fracos de cultura". ${ }^{100} \bigcirc$ oficial de gabinete aliou essas considerações a outras acerca da alta qualidade dos vinhos e das refeições servidas no Palácio e - pior - teve a insolência de, em um lugar com tantas carências, tratá-las entre as realizações do governo! Nem a desculpa de favorecer as artes e a cultura nacional poderia ser aventada, uma vez que parte dos quadros e os vinhos eram importados. Ao lado do episódio do Grande Hotel e da Biblioteca Pública, esses são indícios de um governo desorientado, pouco sincronizado não apenas com seu contexto, mas com sua própria agenda. Se Freyre conseguia identificar tão bem o mau-gosto de "novos-ricos, novos-cultos e novospoderosos", 101 escapava-the a desorientação na qual se encontravam, naquele momento, setores das elites tradicionais pernambucanas, nas quais se incluía.

A delicadeza no tratamento da cidade histórica durante o governo de Sergio Loreto não merece ser tratada como casualidade, nem ser desvinculada de Amaury, a quem muitos observadores da época atribuíram papel central na orientação dessa administração. Um mérito como sanitarista que the pode ser atribuído foi o de ter superado os limites da higiene no tratamento da cidade. É possível que seu feito mais surpreendente - aquele que mais deve ter-the custado esforço, reflexão e modéstia - tenha sido seu reposicionamento em face à cidade antiga. Em meio a uma atividade febril como sanitarista e imbuído pelo "mysticismo higienico" próprio aos médicos de sua geração que enveredaram por esse campo, não se negou a repensar os efeitos dessa ação sobre vestígios do passado. Teve capacidade, sensibilidade e elegância para uma importante autocrítica, não explícita em textos, mas que pode ser apreendida em algumas de suas falas e nas ações do governo de Sergio Loreto. Um reposicionamento que the exigiu rever alguns dos métodos correntes de ação da higiene para conciliá-los com a defesa da cidade herdada do passado. Na sua cruzada sanitária, Amaury foi capaz de não usar seu prestígio junto ao governador e seu notório entusiasmo e operosidade em uma investida contra os bairros antigos do Recife, rasgando ruas e pondo abaixo casarões, guiado pelas convicções higienistas que defendia na chefia dos serviços de saúde de Pernambuco. Recuou, enxergou mais que riscos à saúde na cidade do passado e, assim, conseguiu ir além do esperado de um sanitarista de seu tempo. Um feito reconhecido por Gilberto Freyre, que acompanhou com grande atenção crítica suas ações.
100. Id. (1973, p. 40).

101. Id. (1925b, p. 3). 
102. Id. (1996, p. 91).

103. Id. (1979c, p. 393).

\section{ALÉM DE FREYRE}

As realizações e eventos inspirados pelo sentimento regionalista, promovidos no Recife entre 1923 e 1926, no âmbito de arquitetura, urbanismo, literatura, culinária, teatro e música, indicam o quanto a leitura do Movimento Regionalista é prejudicada pela atenção insuficiente dada ao papel desempenhado por seus vários integrantes e pelas diferentes abordagens por eles trazidas à questão regional.

A literatura posterior enfatizou muito a liderança intelectual de Gilberto Freyre, a quem quase se chegou a reduzir todo o movimento. $\bigcirc$ prestígio intelectual de Freyre em 1924 - legitimado por seu brilho, mestrado em Columbia e posição no Diario de Pernambuco - é indiscutível, assim como seu papel central no centro em termos de divulgação das ideias e contribuição teórica. Ao jovem e inquieto sociólogo e jornalista coube - na função de secretário-geral - participar da condução de todas as iniciativas e ser o principal intérprete das ideias que moviam o grupo. Contudo, o posterior crescente prestígio de Freyre pode ter contribuído para acentuar de forma desmedida a importância de seu papel no movimento. Ao publicar o Manifesto Regionalista, no qual traduz os objetivos do movimento, o próprio Freyre contribuiu para ofuscar as contradições internas do grupo e reduzir as contribuições de outros de seus membros. O Manifesto é um documento ambíguo, apresentado por Freyre em 1951, em um evento realizado no Instituto Joaquim Nabuco de Pesquisas Sociais, e publicado, pela primeira vez, no ano seguinte. $\bigcirc$ autor afirma ser o que havia lido no Congresso Regionalista, ao qual teria feito "[...] alguns pequenos acréscimos à reconstituição do manuscrito há anos abandonado". 102 Contudo, além do tema de sua conferência no congresso - a culinária nordestina -, o documento inclui vários outros. É difícil avaliar a extensão do acréscimo realizado, uma vez que Freyre informa que a conferência original teria sido publicada apenas parcialmente, em 1926, pelo Diario de Pernambuco. Entretanto, mais que ajustes no conteúdo da conferência, importa a operação de alçá-la a manifesto e, com isto, conduzir Freyre à condição de porta-voz do Movimento Regionalista. Durante o congresso, nenhuma conferência foi tratada como manifesto e se alguma se aproximou dessa condição, não há porque duvidar de que teria sido a realizada na abertura do evento por Moraes Coutinho. Odilon Nestor presidiu a sessão, ocorrida 1951, na qual o manifesto foi lido e não contestou sua autenticidade, atitude previsível naquelas circunstâncias, que incluíam sua idade avançada e as homenagens que recebeu de Freyre na cerimônia. De autor de Manifesto e porta-voz do movimento, Freyre reivindicou, em seguida, a condição de organizador do congresso, conforme consta em Tempo de Aprendiz: "Em 1926 organizou a primeiro Congresso Regionalista que se realizou nas Américas [...]". ${ }^{103}$ 
Em outra obra, Freyre escreve que Amaury "aderira com lúcido entusiasmo ao programa do Centro Regionalista", 104 omitindo que o médico foi um dos seis fundadores e esteve entre os membros mais ativos da associação, com a qual sua relação não foi, efetivamente, de adesão. Amaury foi essencial às realizações do centro pelo apoio institucional que proporcionou às iniciativas e, como reconheceu Freyre, pelo seu temperamento agitado e "volúpia das realizações", que impulsionaram as iniciativas do grupo. Não custa lembrar que a saída de Amaury do Recife, em outubro de 1926, coincidiu com o momento no qual minguaram e, em seguida, cessaram as atividades do centro: o Segundo Congresso Regionalista do Nordeste, sugerido por Freyre para ocorrer em 1927, na Paraíba, nunca se realizou, assim como não há notícias que tenha ocorrido "O Mez da Cidade", previsto pelo sociólogo, em outubro de 1926, para o final desse ano ou início do seguinte. A desmobilização do movimento se deu a ponto de Freyre ter se sentido à vontade para se colocar como seu porta-voz, mentor, ideólogo e principal representante. Pareceu não perceber que, ampliando seu papel, reduzia o movimento.

A ideia dessa suposta liderança isolada e inconteste de Freyre sobre os regionalistas prejudica a compreensão da complexidade e das contradições internas de um grupo plural nos mais diferentes sentidos: faixa etária, formação, posição social, concepções políticas e motivações. A visão distorcida do papel de Freyre emprestou ao movimento uma unidade maior que aquela possível, quando reuniu sanitaristas e conservacionistas, saudosistas e reformistas, funcionários públicos e usineiros, jornalistas e donos de jornais, jovens inquietos e idosos carregados de lembranças... O grupo compartilhava o interesse pelas coisas regionais, o compromisso de valorizá-las e a concepção do valor delas para a recriação ou inovação no campo das artes, da literatura, da arquitetura e do urbanismo. A partir daí os consensos cessavam. Em termos de motivações, é possivel cogitar as mais diversas, entre as quais pode ser aventada uma resistência empenhada em oferecer à cultura nacional uma contribuição original e autêntica; a afirmação de oligarquias rurais; a valorização da cultura popular; e o reconhecimento da cultura do interior e do sertão, desprezadas no ambiente que se pretendia cosmopolita do Recife. Tal diversidade de perspectivas e posições fica patente no congresso: violeiros cantam e Ascenso mostra seus versos; come-se camarão dos mangues do litoral e queijo do sertão.

A ênfase colocada em Freyre contribuiu para se desprezar a adesão do governo de Sergio Loreto ao programa regionalista, atestada pelo conteúdo da Revista de Pernambuco, pelo programa da Exposição Geral de Pernambuco, por eventos culinários, pela promoção do estilo neocolonial em prédios públicos, pela criação de 
jardins públicos com espécimes da flora local e pela ausência, quase total, de obras públicas que implicassem a destruição de construções e bairros antigos.

Os embates travados entre Freyre e Amaury, em torno da relação entre higiene e tradição, foram mais uma face instigante do Movimento Regionalista, que a ênfase excessiva no papel desempenhado por Freyre contribui para ocultar. 


\section{REFERÊNCIAS}

Fontes manuscritas

GRUPO Escolar Amaury de Medeiros. Projecto. Elevação Frente. DAEIOP - Secção de Obras. Escala: 1/50. APEJE, Setor de Iconografia.

HOSPITAL Oswaldo Cruz. Pavilhão da Administração. Projecto. DGVOP - Secção de Obras. Escalas: planta, 1/100; fachadas e cortes, 1/50. APEJE, Setor de Iconografia.

PAVILHÃO de Observações. Hospital de Doenças Nervosas e Mentaes. DGVOP - Secção de Obras. Projecto Elevação. Escala: 1/50. APEJE, Setor de Iconografia.

FONTES IMPRESSAS

$1^{\circ}$ CONGRESSO Regionalista do Nordeste. A Provincia, a. LV, n. 33. Recife, 9 fev. 1926a. p. 1.

$1^{\circ}$ CONGRESSO Regionalista do Nordeste. A Provincia. a. LV, n. 34 . Recife, 10 de fev. de 1926 b, p. 3.

$1^{\circ}$ CONGRESSO Regionalista do Nordeste. A Provincia. a. LV, n. 35. Recife, 11 fev. 1926c, p. 5.

A EXPOSIÇÃO. Diario de Pernambuco, a. 99, n. 265. Recife, 13 nov. 1924. p. 3.

A SEMANA das Árvores. Diario de Pernambuco, a. 99, n. 264. Recife, 12 nov. 1924. p. 1.

BELLO, Julio. Recife Velho. Diario de Pernambuco, a. 100, n. 242. Recife, 18 out.1925. p. 2.

CENTRO Regionalista do Nordeste. Diario de Pernambuco, a. 100, n. 53. Recife, 5 mar. 1925a. p. 1.

CENTRO Regionalista do Nordeste. Diario de Pernambuco, a. 100, n. 71. Recife, 26 mar. 1925b. p. 3.

CENTRO Regionalista do Nordeste. Diario de Pernambuco, a. 99, n. 202. Recife, 2 set. 1924a. p. 3. 
CENTRO Regionalista. Diario de Pernambuco, a. 99, n. 105. Recife, 7 mai. 1924b. p. 1.

CONGRESSO Regionalista. Rua Nova, Recife, a. II, n. 49, abril 1926, p. 26.

CONGRESSO Regionalista do Nordeste. Revista de Pernambuco, Recife, a. II, n. 21, abril de 1926, p. 63.

DR. AMAURY de Medeiros. Jornal do Recife, a. LXVI, n. 238. Recife, 12 out. 1923. p. 1.

DR. SERGIO Loreto. Diario de Pernambuco, a. 99, n. 244. Recife, 19 out. 1924a. p. 3.

DR. SERGIO Loreto. Diario de Pernambuco, a. 99, n. 245. Recife, 21 out. 1924b. p. 3.

ECHOS da "Semana das Arvores". Diario de Pernambuco, a. 99, n. 267. Recife, 15 nov. 1924. p. 4.

EXCURSÃO do Governador do Estado a Nazareth e Timbaúba. Revista de Pernambuco, Recife, a. 3, n. 27 , setembro 1926 .

FERNANDES, Annibal. Arte Civica e Religiosa em Pernambuco. O Jornal, a. X, Edição Especial Pernambuco. Rio de Janeiro, 17 set. 1928. p. 3.

FERNANDES, Annibal. Cousas da Cidade. Diario de Pernambuco, a. 101, n. 65. Recife, 19 mar. 1926. p. 3 .

FERNANDES, Annibal. Gilberto Freyre. Diario de Pernambuco, a. 98, n. 55. Recife, 8 mar. 1923. p. 3.

FREITAS, Octavio de. A importancia do registro sanitario das habitações como instrumento de defesa hygienica das collectividades. In: Annaes do Primeiro Congresso Medico de Pernambuco. Recife: Typographia do Diario de Pernambuco, 1910.

FREITAS, Octavio de. Os Trabalhos de Hygiene em Pernambuco. Relatorio Apresentado ao Secretario Geral do Estado. Recife: Officinas Graphicas da Imprensa Official, 1919.

FREYRE, Gilberto. 14. Diario de Pernambuco, a. 99, n. 169. Recife, 23 jul. 1923a. p. 3.

FREYRE, Gilberto. 19. Diario de Pernambuco, a. 99, n. 198. Recife, 26 ago. 1923b. p. 1. 
FREYRE, Gilberto. 3. Diario de Pernambuco, a. 99, n. 103. Recife, 6 mai. 1923c. p. 1.

FREYRE, Gilberto. 55. Diario de Pernambuco, a. 99, n. 103. Recife, 4 mai. 1924a. p. 3.

FREYRE, Gilberto. 68. Diario de Pernambuco, a. 99, n. 178. Recife, 13 nov. 1924b. p. 1.

FREYRE, Gilberto. 75. Diario de Pernambuco, a. 99, n. 220. Recife, 21 set. 1924c. p. 3.

FREYRE, Gilberto. Diario de Pernambuco, a. 101, n. 51. Recife, 3 mar. 1926a. p. 3.

FREYRE, Gilberto. Diario de Pernambuco, a. 99, n. 35. Recife, 10 fev. 1924d. p. 2.

FREYRE, Gilberto. Espirito e não estylo. Diario de Pernambuco, a. 101, n. 43. Recife, 21 fev. 1926b. p. 1.

FREYRE, Gilberto. Nordeste Separatista? Diario de Pernambuco, a. 101, n. 71. Recife, 29 mar. 1926c. p. 3.

FREYRE, Gilberto. O Livro do sr. Amaury de Medeiros. Diario de Pernambuco, a. 101, n. 253. Recife, 7 nov. 1926d. p. 3.

FREYRE, Gilberto. O mez da cidade. Diario de Pernambuco, a. 101, n. 252. Recife, 31 out. 1926e. p. 1.

FREYRE, Gilberto. O Recife e as Arvores. Diario de Pernambuco, a. 99, n. 265. Recife, 13 nov. 1924d. p. 4-5.

FREYRE, Gilberto. Os Discursos do sr. Amaury de Medeiros. Diario de Pernambuco, a. 99, n. 203. Recife, 2 set. 1924 e. p. 3 .

FREYRE, Gilberto. Pernambuco de Longe. Diario de Pernambuco, a. 101, n. 96. Recife, 27 abr. 1926f. p. 3.

FREYRE, Gilberto. Physionomia das Novas Cidades. Diario de Pernambuco, a. 100, n. 65. Recife, 19 mar. 1925a. p. 3.

FREYRE, Gilberto. Reacção do Bom Gosto. Diario de Pernambuco, a. 100, n. 271. Recife, 24 nov. 1925b. p. 3. 
FREYRE, Gilberto. Regionalismo Creador. Diario de Pernambuco, a. 100, n. 71. Recife, 26 mar. 1925c. p. 3.

FREYRE, Gilberto. Restauração Opportuna. Diario de Pernambuco, a. 99, n. 242. Recife, 18 out. 1924f. p. 2.

FREYRE, Gilberto. Um Consolo. Diario de Pernambuco, a. 99, n. 229. Recife, 2 out. 1924g. p. 3.

GILBERTO Freyre. Diario de Pernambuco, a. 98, n. 72. Recife, 28 mar. 1923d. p. 1.

GOVERNO que educa. Jornal do Recife, a. LXVI, n. 146. Recife, 26 jun. 1923. p. 1.

ILLUSTRAÇÃO Brasileira, Rio de Janeiro, a. V, n. 46, junho 1924.

INAUGURAÇÃO da “Casa Operaria”. Revista de Pernambuco, Recife, a. II, n. 11, maio 1925.

MARIANNO FILHO, José. Os dez mandamentos do estylo neo-colonial. Diario de Pernambuco, a. 99, n. 52. Recife, 6 abr. 1924. p. 2.

MEDEIROS, Amaury de. Novos Bandeirantes, Velhos Rumos... OJornal, a. X, Edição Especial Pernambuco, $3^{\text {a }}$ Secção. Rio de Janeiro, 17 set. 1928. p. 20.

MEDEIROS, Amaury de. Pernambuco e o problema sanitario do nordeste. Illustração Brasileira. Rio de Janeiro, a. V, n. 46, junho 1924.

MEDEIROS, Amaury. Primeiro Congresso Regionalista do Nordeste. Diario de Pernambuco, a. 101, n. 33. Recife, 9 fev. 1926b. p. 3.

MEDEIROS, Amaury. Primeiro Congresso Regionalista do Nordeste. Diario de Pernambuco, a. 101, n. 36. Recife, 12 fev. 1926c. p. 3.

MELlO Mario. A Propósito de Artes Retrospectivas. Diario de Pernambuco, a. 100, n. 109. Recife, 13 mai. 1925. p. 3.

O REGIONALISMO Como Expressão de Nacionalismo. O Jornal, a. VIII, n. 2239. Rio de Janeiro, 2 abr. 1926. p. 2.

PINTO, Estevão. A Casa Brasileira. Revista de Pernambuco, Recife, a. 3, n. 21, março 1926. 
PRIMEIRO Congresso Region alista do Nordeste. Diario de Pernambuco, a. 101, n. 33. Recife, 9 fev. 1926a. p. 3.

PRIMEIRO Congresso Regionalista do Nordeste. Diario de Pernambuco, a. 101, n. 34. Recife, 10 fev. 1926 b. p. 3.

PRIMEIRO Congresso Regionalista do Nordeste. Diario de Pernambuco, a. 101, n. 224. Recife, 27 set. 1926 c. p. 4.

QUARTO Congresso Brasileiro de Hygiene. OJornal, a. X, n. 2807. Rio de Janeiro, 26 jan. 1928. p. 7.

REVISTA de Pernambuco, Recife, a. III, n. 23, maio 1926.

RIALTO, Jorge. O anno de 1928. A Provincia, a. LVII, n. 289. Recife, 13 dez. 1928a. p. 3.

RIALTO, Jorge. Uma recordação. A Provincia, a. LVII, n. 283. Recife, 6 dez. 1928b. p. 3.

LIVROS, ARTIGOS E TESES

CORREIA, Telma de Barros. A construção do habitat moderno no Brasil, 1870-1950. São Carlos: Rima, 2004.

CORREIA, Telma de Barros. Ornato e Despojamento no Mundo Fabril. Anais do Museu Paulista, v. 19, n. 1, p. 11-80, 2011.

CORREIA, Telma de Barros. Patrimônio Industrial e Agroindustrial no Brasil: a forma e a arquitetura dos conjuntos industriais. In: Espaços de Produção: arquitetura, paisagens e patrimônio. Org. CORREIA, Telma de Barros; BORTOLUCCI Maria Ângela. São Paulo: Annablume, 2013. p. 183-206.

CORREIA, Telma de Barros; GUNN, Philip. Saúde Pública e as Reformas de Paula Souza. in: PHILIPPI JR, Arlindo; ROMERO, Marcelo de Andrade; BRUNA, Gilda Collet (orgs.). Curso de Gestão Ambiental. Barueri: Manole, 2014a. p. 451-468.

CORREIA, Telma de Barros. Arquitetura e Paisagem Industrial: as vilas operárias no Recife. Estudos Universitários, v. 32. Recife, p. 149-173, 2014 b. 
COUTINHO, Aluízio Bezerra. O problema da habitação higiênica nos paises quentes em face da Arquitetura Viva. Rio de Janeiro: Officinas Alba Graphicas, 1930.

FONSECA, Edson N. O Recife de Manuel Bandeira. Recife: Pool, 1986.

FREITAS, Octavio de. Os Nossos Medicos e a Nossa Medicina. Recife: Typ. D’A Provincia, 1904.

FREYRE, Gilberto. Estácio Coimbra: aspectos de uma figura já histórica e ainda contemporânea. In: FREYRE, Gilberto. Estácio Coimbra, homem representativo do seu meio e do seu tempo. Recife: IJNPS-MEC, 1973. p. 29-44.

FREYRE, Gilberto. Guia Prático, Histórico e Sentimental da Cidade do Recife. $4^{a}$ ed. Rio de Janeiro: José Olympio Ed., 1968.

FREYRE, Gilberto. Livro do Nordeste. Ed. Fac-similada. Recife: Secretaria da Justiça; Arquivo Público Estadual, 1979a.

FREYRE, Gilberto. Manifesto Regionalista. $7^{\mathrm{a}}$ ed. Recife: FUNDAJ, Ed. Massangana, 1996.

FREYRE, Gilberto. Mucambos do Nordeste. Algumas Notas Sobre o Typo de Casa Popular mais Primitivo do Nordeste do Brasil. Rio de Janeiro: Ministério da Educação e Saúde, 1937.

FREYRE, Gilberto. Oh de casa! Em torno da casa brasileira e de sua projeção sobre o tipo nacional de homem. Recife: IJNPS, 1979b.

FREYRE, Gilberto. Tempo de Aprendiz. v. II. São Paulo: IBRASA; Brasília: INL, 1979c.

MEDEIROS, Amaury de. Saude e Assistencia. Doutrinas, experiencias e realizações 1923-1926. Recife: Graphica Pimenta de Mello \& Cia. (Rio de Janeiro), 1926a.

REVISTA do APEJE. Recife, a. 1, n. 1, abr./mai./jul. 2016.

SOUZA BARROS, Manuel de. A Década de 20 em Pernambuco: uma interpretação. Recife: Prefeitura da Cidade do Recife/Fundação de Cultura Cidade do Recife, 1985.

Artigo apresentado em 25/09/2019. Aprovado em 05/02/2020. (cc) BY

All the contents of this journal, except where otherwise noted, is licensed under a Creative Commons Attribution License 